\title{
Behavioural effects of compounds co-consumed in dietary forms of caffeinated plants
}

\author{
C. F. Haskell*, F. L. Dodd, E. L. Wightman and D. O. Kennedy \\ Faculty of Health and Life Sciences, Brain, Performance and Nutrition Research Centre, Northumbria University, \\ Newcastle upon Tyne NE1 8ST, UK
}

\begin{abstract}
Research into the cognitive and mood effects of caffeine in human subjects has highlighted some fairly robust and well-accepted effects. However, the majority of these studies have focused on caffeine in isolation; whilst caffeine is normally consumed in the form of plantderived products and extracts that invariably contain other potentially bioactive phytochemicals. The aim of the present review is to consider the possible mechanisms of action of co-occurring phytochemicals, and any epidemiological evidence suggesting that they contribute to potential health benefits ascribed to caffeine. Intervention studies to date that have been conducted to explore the effects on brain function of the non-caffeine components in caffeine-bearing plants (coffee, tea, cocoa, guaraná), either alone or in combination with caffeine, will also be summarised. Research is beginning to accumulate showing independent effects for several of the phytochemicals that co-occur with caffeine, and/or a modulation of the effects of caffeine when it is co-consumed with these naturally concomitant phytochemicals. The present review highlights that more research aimed at understanding the effects of these compounds is needed and, more importantly, the synergistic relationship that they may have with caffeine.
\end{abstract}

Key words: Brain function: Cognition: Mood: Phenolic compounds: Caffeine plants

\section{Introduction}

Caffeine is found naturally in over sixty species of plants, a number of which are consumed for their psychoactive effects, including coffee (Coffea robusta/arabica), tea (Camellia sinensis), cocoa (Theobroma cacao), guaraná (Paullinia cupana), yerba maté (Ilex paraguariensis) and kola nut (Cola nitida/acuminata). These plants, or extracts of them, are regularly consumed as part of a normal diet, although caffeine can also be found in a number of other caffeine-containing products, such as soft drinks and medications. As a result, caffeine is consumed by the majority of the population in one form or another, with a study by Heatherley et al. ${ }^{(1)}$ demonstrating that $91 \%$ of a UK sample consumed daily caffeine amounts equivalent to at least one cup of tea. Although caffeinated beverage preferences differ across countries ${ }^{(2)}$, tea and coffee represent the main sources of caffeine and are second only to water in terms of worldwide beverage consumption. It is therefore of great importance that we fully understand the health implications of these dietary components. Research into the effects of caffeine, as the main active compound within these beverages, is abundant, with the first investigation into its effects on behaviour being conducted in $1912^{(3)}$.
However, the other compounds within these, prolific beverages have received surprisingly little research attention in terms of either their own independent psychoactive effects, or their ability to modify the behavioural effects of caffeine with which they are co-consumed. The aim of the present article is to provide a qualitative review of the literature to date examining behavioural effects of the main compounds consumed with caffeine. This will draw upon mechanistic and epidemiological data suggesting effects relevant to health before moving on to the main focus, intervention trials. Key issues to be considered are the quantities administered, the time-frame over which effects are monitored and the measures employed to assess any effects.

\section{Caffeine}

Caffeine is rapidly absorbed and distributed, with peak plasma levels being reached at about $30 \mathrm{~min}$ postingestion $^{(4)}$. The action of caffeine is largely the result of antagonism of adenosine receptors, specifically $\mathrm{A}_{1}$ and $\mathrm{A}_{2 \mathrm{~A}}$ sub-receptors ${ }^{(2)}$. This blockade of the inhibitory action of adenosine has been linked to increased levels of dopamine, acetylcholine, noradrenaline, serotonin, glutamate

Abbreviations: AD, Alzheimer's disease; CBF, cerebral blood flow; EEG, electroencephalogram; EGCG, epigallocatechin gallate.

*Corresponding author: Dr C. F. Haskell, fax + 44191 22,74515, email crystal.haskell@northumbria.ac.uk 
and $\gamma$-aminobutyric acid ${ }^{(5)}$. In terms of vascular effects, despite exerting endothelium-dependent vasodilation via modulation of nitric oxide (NO) synthesis, caffeine has a net effect of reduced cerebral blood flow (CBF) as a consequence of vasoconstriction mediated by adenosine receptor antagonism ${ }^{(6)}$.

The most widely accepted behavioural effect of caffeine is an increase in alertness, an effect that has been demonstrated in numerous studies (for example, Quinlan et al. ${ }^{(7)}$, Smit \& Rogers $^{(8)}$ and Smith et al. $\left.{ }^{(9)}\right)$. Improvements to cognition, particularly reaction time (for example, Smit \& Rogers ${ }^{(8)}$ and Durlach et $a l .{ }^{(10)}$ ) and vigilance (for example, Brice \& Smith $^{(11)}$ and Childs \& de Wit ${ }^{(12)}$ ) are also well documented. It has been suggested that these effects merely represent alleviation of withdrawal in habitual caffeine consumers ${ }^{(13)}$. However, comparisons of low/non-caffeine consumers' and regular consumers' behavioural responses to caffeine have demonstrated similar effects irrespective of habitual caffeine intake ${ }^{(14,15)}$, even when there is no evidence of withdrawal in the habitual consumers ${ }^{(16-18)}$. There are, however, issues regarding the methodologies employed to test this suggestion, such as the possibility of nonconsumers developing tolerance to these effects following repeated consumption of caffeine (for a review, see James \& Rogers $\left.{ }^{(19)}\right)$, and this is an area that requires further research before a definitive conclusion can be reached.

The majority of effects of caffeinated plants and beverages may be explained by the presence of caffeine. However, caffeinated plants contain a number of other components that either have their own direct action on the central nervous system or work indirectly to modulate the effects of caffeine.

\section{Concomitant active components and their mechanisms}

There are many phytochemicals present in natural sources of caffeine that have the potential to exert myriad independent, synergistic, additive or antagonistic effects to those of caffeine. These potentially bioactive phytochemicals are predominantly phenolic compounds, and in particular polyphenols, which contain multiple phenolic substructures. The one major exception to this is the amino acid L-theanine, which is present in tea and which modifies the activity of caffeine (see below). The primary phenolic compounds contained within tea are a range of flavan3-ols, or catechins, of which epigallocatechin gallate (EGCG) predominates. However, tea also contains appreciable levels of the flavonol quercetin, phenolic acids, and, in the case of black tea, a range of theaflavins formed by the oxidation of the flavan-3-ols ${ }^{(20,21)}$. Similarly, cocoa primarily contains flavan-3-ols, including catechin and epicatechin, along with their oligomer chain products proanthocyanidins ${ }^{(22)}$, and guaraná includes substantial amounts of, as yet ill-defined, tannins and flavan-3-ols ${ }^{(23)}$. The principal non-caffeine components in coffee comprise simpler phenolics, in particular chlorogenic acids, which are formed by esterification of several phenolic acids, most notably caffeic acid, and also quinic acid ${ }^{(21)}$. Chlorogenic acid lactones, which may have independent effects on brain function, are also formed during roasting ${ }^{(24)}$.

Phenolics possess a number of properties that might underlie their purported health-promoting properties. Most pertinently, the notion that phenolics function as exogenous antioxidants has given way to an appreciation that phenolics such as polyphenols, and flavonoids in particular, interact with a number of cellular immune/stress signalling pathways ${ }^{(25)}$. In vitro and in/ex vivo research suggests that one common over-arching mechanism in this respect is modulation of multifarious elements of the protein kinase signalling pathways that connect extracellular stimuli, detected by membrane receptors, via signalling cascades (such as mitogen-activated protein kinase), to cellular changes and gene transcription. In terms of brain function, research suggests that the downstream effects of these flavonoid/signalling interactions include regulation of the expression of inflammatory factors such as cytokines, prostaglandins, and inducible NO synthase; neuroprotective effects, increased neurogenesis, and modulated vascular function via interactions with NO synthases ${ }^{(26,27)}$.

To give one relevant example, the most abundant flavonoid in tea, EGCG, has been associated with a plethora of potentially beneficial effects in vitro/vivo, including in the face of neurodegenerative disorders ${ }^{(28,29)}$ and dementia $^{(30,31)}$. It is likely that the ability of EGCG to modulate signal transduction pathways, including protein kinases, and therefore cellular stress responses and survival ${ }^{(32)}$, underlies benefits in terms of inflammatory parameters ${ }^{(33)}$, mitochondrial function (for a review, see Mandel et al. ${ }^{(34)}$ ), protection against dopaminergic neurodegeneration ${ }^{(35)}$ and up-regulation of a number of endogenous mammalian antioxidant enzymes ${ }^{(35-37)}$, with this latter effect abolished by inhibition of protein kinase $\mathrm{C}^{(35)}$. Amelioration of oxidative damage following EGCG administration has also been associated with preserved cognitive function in rodents following a variety of neuronal insults ${ }^{(38-41)}$. A further key mechanism of action of this flavonoid may be its potential to modulate blood flow, both in the periphery and the brain, via complex modulation of the expression of the three isoforms of NO synthase ${ }^{(42-45)}$, which results in changes in vasodilation in the peripheral vasculature of animals $^{(45-48)}$, and in humans with coronary artery disease ${ }^{(49)}$. Similar effects have also been observed in healthy non-smokers ${ }^{(50,51)}$ and smokers ${ }^{(52)}$ following the consumption of tea.

Studies exploring vascular effects of cocoa have produced similar results to those of EGCG. A number of observational studies have demonstrated a negative relationship between habitual cocoa intake and blood pressure ${ }^{(53-55)}$. This is supported by cocoa intervention studies showing a reduction in blood pressure in healthy participants ${ }^{(56,57)}$, as well as in participants who are overweight $^{(58,59)}$ and in those with evidence of glucose 
intolerance or cardiovascular risk factors ${ }^{(60-63)}$. Others have failed to demonstrate these effects whether studying healthy participants or otherwise ${ }^{(64-70)}$ but meta-analyses have supported a case for anti-hypertensive effects of $\operatorname{cocoa}^{(71-73)}$. A number of studies have also explored effects of cocoa on flow-mediated dilation, an endotheliumdependent measure of vasodilation and a marker for NO availability. Significant increases in flow-mediated dilation have been demonstrated across a similar range of populations as studied in relation to blood pressure (many of whom suffer from endothelial dysfunction), whether studied chronically over periods of $8 \mathrm{~d}$ to 12 weeks $(60,62,63,65,70)$, or acutely at $2 \mathrm{~h}$ post-administration ${ }^{(58,59,65,66,68,74,75)}$. This acute effect of cocoa on flow-mediated dilation is correlated with increases in plasma NO species ${ }^{(66,74)}$. Inverse relationships have also been observed between chocolate consumption and $\mathrm{CHD}^{(55)}$, cardiac mortality following acute myocardial infarction ${ }^{(76)}$ and heart failure ${ }^{(77,78)}$. This latter study also showed that frequent chocolate consumers had a significantly lower prevalence of carotid atherosclerotic plaques. A significant inverse association between chocolate consumption and total stroke, cerebral infarction and haemorrhagic stroke has also been observed, with a stronger association for haemorrhagic stroke than cerebral infarction $^{(79)}$. Support for these findings comes from a recent systematic review of observational studies showing that cocoa consumption was associated with a $29 \%$ reduction in risk of stroke, a relationship that survived adjustment for potential confounders ${ }^{(80)}$. Studies in mice have also observed that epicatechin in isolation may aid the prevention of stroke damage through the Nrf2/HO1 (nuclear factor (erythroidderived 2)-like 2 /haeme oxygenase-1) pathway ${ }^{(81)}$.

Whilst the phenolic coffee chlorogenic acids have not benefitted from as much research as EGCG or cocoa flavan-3-ols, in vitro evidence does suggest that both chlorogenic acid and chlorogenic acid lactones interact with mitogen-activated protein kinase signalling pathways, bolstering antioxidant and neuroprotective properties ${ }^{(82)}$. In vivo these effects translate, for instance, into improved cognitive function in rodents in the face of a scopolamine challenge, with concomitant up-regulation of endogenous antioxidant systems, and additional cholinesterase inhibition in healthy rats ${ }^{(83)}$. Any interaction with signalling pathways could feasibly underlie the few direct demonstrations of altered brain function in humans by polyphenols, including those instances of modulated brain function described below with respect to EGCG, chlorogenic acid and cocoa flavan-3-ols.

The majority of research into the neuropharmacology of L-theanine has involved animal studies and therefore its mechanism of action in humans has yet to be wholly understood. L-Theanine is a derivative of, and has a chemical structure similar to that of, the neurotransmitter glutamic acid ${ }^{(84)}$. It crosses the blood-brain barrier via the leucine-preferring transport system $^{(85)}$ and has been shown to influence neurotransmitter concentrations.
Levels of dopamine in the rat striatum were increased in a dose-dependent manner following L-theanine ${ }^{(85)}$, as were those of $\gamma$-aminobutyric acid when L-theanine was administered intraperitoneally to mice ${ }^{(86)}$. Modulation of serotonin levels has also been observed. Yokogoshi et $a l .{ }^{(87)}$ reported a dose-dependent reduction in levels of serotonin in the brain of spontaneously hypertensive and Wistar-Kyoto rats. A later study also demonstrated decreased global brain serotonin following L-theanine administration; however, region-specific increases were observed in the striatum, hippocampus and hypothalamus ${ }^{(85)}$. A putative glutamate antagonist, $\mathrm{L}$-theanine is capable of binding to the glutamate receptor subtypes AMPA ( $\alpha$-amino-3-hydroxy-5-methylisoxazole-4-propionic acid), kainite and NMDA ( $N$-methyl-D-aspartate) glycine ${ }^{(88)}$. This antagonism of glutamate receptors by L-theanine has been linked to neuroprotection against cerebral ischaemia when administered intraperitoneally to mice ${ }^{(89)}$ and via intracerebroventricular injection to gerbils ${ }^{(90)}$.

\section{Epidemiological evidence}

Support for mechanistic studies described above, that imply a role for components other than caffeine in the effects of caffeinated products on behaviour, comes from epidemiological evidence showing differential effects on cognition as a function of caffeine source. In one of the first epidemiological studies of caffeine's effects on behaviour, Jarvis ${ }^{(91)}$ showed a significant dose-response relationship between habitual caffeine consumption and performance of both simple and choice reaction time tasks after controlling for sociodemographic, lifestyle and health factors. These effects were more apparent in older, rather than younger, participants, which may indicate a cumulative effect of habitual caffeine consumption on cognitive performance, or may simply indicate a greater scope for improvement in older volunteers. Nevertheless, these data suggest that tolerance to the effects of caffeine is incomplete. The study also showed that the relationship across all ages was stronger for coffee than for tea. Given the dose-response relationship between caffeine and performance, this favourable correlation for coffee may simply be indicative of the higher caffeine levels present. It is also important to note that recent caffeine intake was not monitored in this study, so the possibility that the relationship reflects acute effects of caffeine/caffeinated beverage consumption cannot be ruled out. A number of other studies have provided evidence in support of a relationship between caffeine and cognitive performance, but no attempt was made to differentiate these effects as a function of caffeine source ${ }^{(92-94)}$. The latter of these studies found that caffeine consumption did not relate to dementia risk over a 4-year period. This is contrary to the findings of Maia \& de Mendonca ${ }^{(95)}$ who carried out a retrospective study of caffeine consumption in fifty-four patients with probable Alzheimer's disease (AD) and fifty-four matched 
control participants, finding that caffeine intake in the 20 years preceding diagnosis of $\mathrm{AD}$ was inversely related with AD. A similar finding was reported by Lindsay et al. ${ }^{(96)}$, but only coffee consumption was negatively related with $\mathrm{AD}$; there were no effects for tea consumption, a finding supported by Eskelinen et al. ${ }^{(97)}$.

When considering the effects of coffee consumption on cognitive decline in older adults, Johnson-Kozlow et al. ${ }^{(98)}$ demonstrated a significant positive association between coffee consumption and cognitive performance. This effect was only observed in women. Interestingly, this study also explored the effects of decaffeinated coffee and found no such associations, in either sex, indicating the importance of caffeine to these effects. van Gelder et al. ${ }^{(99)}$ explored the effects of coffee consumption in men only, finding an inverse relationship between consumption and cognitive decline. Similar results were presented, in men and women, by Wu et al. ${ }^{(100)}$. Conversely, in a twin study, Laitala et $a l^{(101)}$ failed to show any relationship between coffee consumption in middle age and cognitive performance in old age (approximately 28 years later), after controlling for other, related, sociodemographic and health factors. One explanation for inconsistencies in results is provided by data from Corley et $a l^{(102)}$ who observed a positive relationship between current caffeine consumption and cognitive function but only when caffeine was consumed as ground coffee. A number of studies do not control for the type of coffee consumed, which, when considering effects of noncaffeinated compounds present in coffee, is likely to have effects that are not controlled for even if an attempt is made to correct for caffeine level.

A similar issue exists within epidemiological studies of tea, whereby the brewing method and size of cup are rarely accounted for. Another factor that is likely to be of importance is the type of tea consumed. For instance, Shimbo et $a l^{(103)}$ showed that consumption of caffeinecontaining drinks as a whole was actually related to a higher risk of mental ill health among females in Japan, but when looking specifically at green tea, no such effect was evident. More promisingly, Kuriyama et al. ${ }^{(104)}$ demonstrated a significant inverse relationship between green tea consumption and cognitive impairment, a relationship not observed for black or oolong tea, or coffee. However, in a Chinese community where black and oolong tea were the predominant tea types consumed, $\mathrm{Ng}$ et al. ${ }^{(105)}$ observed a significant inverse relationship between total tea intake and cognitive impairment that was most apparent in relation to black and oolong tea. No association with coffee was observed. In a naturalistic study of tea, Bryan et al. ${ }^{(106)}$ explored the relationship between reported beverage consumption (using the diary method completed four times per d) and subjective work performance, cognitive-affective associates of work performance, mood, work-related strain and recovery. Tea consumption was shown to be negatively related to ratings of tiredness, but this effect was only apparent when sugar was not added to tea. A similar relationship between tea and work performance was observed, whereby higher tea consumption resulted in higher levels of performance but only if consumed without additives (milk, sugar, both). Non-caffeinated beverage consumption positively correlated with relaxation ratings; and evening consumption of non-caffeinated beverages showed a positive relationship with recovery (psychological detachment from work, relaxation and mastery of experiences that provide opportunities for learning).

The impact of flavonoid consumption from a range of caffeinated and non-caffeinated sources on cognitive function and decline has also been explored. The Paquid study explored the role of flavonoid consumption in the development of dementia in 1367 French participants over the age of 65 years with a 5-year follow-up ${ }^{(107)}$. This study demonstrated a significant inverse relationship between flavonoid intake and incidence of dementia. This dataset was further explored by Letenneur et al. ${ }^{(108)}$ who assessed mental state (Mini-Mental State Examination) and cognitive performance at baseline and at re-assessment four times over a 10-year period. A positive relationship between flavonoid intake and cognitive performance at baseline as well as an inverse relationship between intake and cognitive decline over the 10-year follow-up were demonstrated; however, the specific source of flavonoid was not explored in either analysis. Nurk et al. ${ }^{(109)}$ did, however, study the specific relationship of chocolate with cognitive performance, as well as the association of performance with flavonoid-rich tea and wine in approximately 2000 elderly men and women living in Norway. In a multiple adjusted model, they found that, in five out of six cognitive tests, the performance of consumers of chocolate (based on previous year's consumption) was significantly better than that of non-consumers and tea drinkers performed better in four out of six tests as compared with non-tea drinkers. Effects of tea were approximately linear but an increasing intake of chocolate was associated with a plateau in increased performance at $10 \mathrm{~g} / \mathrm{d}$.

Taken together, data from epidemiological studies would seem to indicate that effects on cognitive function and decline are more robust for coffee than tea, with data specifically examining effects of cocoa being too sparse to draw any conclusions. Of the nine studies reviewed above that explored effects of coffee, six showed a positive relationship with cognitive function $^{(91,96-100)}$, whereas only three of the six studies that explored effects of tea showed this relationship ${ }^{(91,104,105)}$, with one of these only showing effects of green tea ${ }^{(104)}$. Of those studies that included both tea and coffee, two observed positive findings of coffee but not tea ${ }^{(96,97)}$, one showed a relationship for both coffee and tea but the effect was stronger for coffee ${ }^{(91)}$, and two showed effects of tea but not coffee ${ }^{(104,105)}$. One possible explanation for these inconsistencies is that studies that failed to 
show benefits of coffee were conducted in countries where consumption of coffee is very low and a similar interpretation can be applied to studies showing a lack of benefits of tea. One potential reason for greater neuroprotective effects of coffee than tea comes from studies showing a positive relationship between coffee and insulin sensitivity (for a review, see Muley et al. ${ }^{(110)}$ ), which may result from reductions in C-peptide levels seen following both caffeinated and decaffeinated coffee consumption ${ }^{(111,112)}$. However, the lack of a relationship between decaffeinated coffee and cognitive decline observed previously suggests that there are other important factors ${ }^{(98)}$

\section{Intervention studies \\ Coffee (Coffea robusta/arabica)}

Despite being one of the most widely consumed beverages in the world, particularly in Western society, research into the effects of coffee per se is limited. A number of studies exist that have explored the effects of caffeinated coffee $v$. decaffeinated coffee ${ }^{(113-116)}$. However, although informative in terms of the effects of caffeine when consumed in combination with other concomitant compounds present in coffee, they do not allow us to assess the impact of these other components. Studies comparing tea and coffee have highlighted some effects of coffee not observed following tea, such as decreased sedation and faster choice reaction time ${ }^{(7,117)}$ (further details are provided below). A number of studies have also explored expectation in relation to the effects of caffeine in different vehicles and, in some cases, this has allowed for an interpretation of the contribution of caffeine, $v$. other components in coffee, to any effects observed. For instance, Andrews et al. ${ }^{(118)}$ demonstrated that decaffeinated coffee significantly lengthened startled blink onset latency as compared with caffeinated coffee, caffeinated juice and non-caffeinated juice. Although this is interpreted in terms of expectation effects and compensatory mechanisms, it is equally possible that this effect is indicative of components within the decaffeinated coffee exerting an action that is modulated (and therefore not observed) when consumed in combination with caffeine. This suggestion was explored by Cropley et al. ${ }^{(119)}$ (see Table 1 for further details) who examined the effects of chlorogenic acid (CGA) on mood and cognition in healthy, elderly participants. Acute effects of CGA were explored by manipulating their levels in a decaffeinated coffee vehicle, producing a regular-CGA decaffeinated condition (224 mg CGA, $5 \mathrm{mg}$ caffeine) and a high-CGA decaffeinated condition (521 mg CGA, $11 \mathrm{mg}$ caffeine) that were compared with each other as well as with caffeinated coffee (244 mg CGA, $167 \mathrm{mg}$ caffeine) and placebo. Although the expected effects of caffeine were observed, very few effects of CGA were detected, with high CGA increasing alertness, and decreasing accuracy of negative bias indices

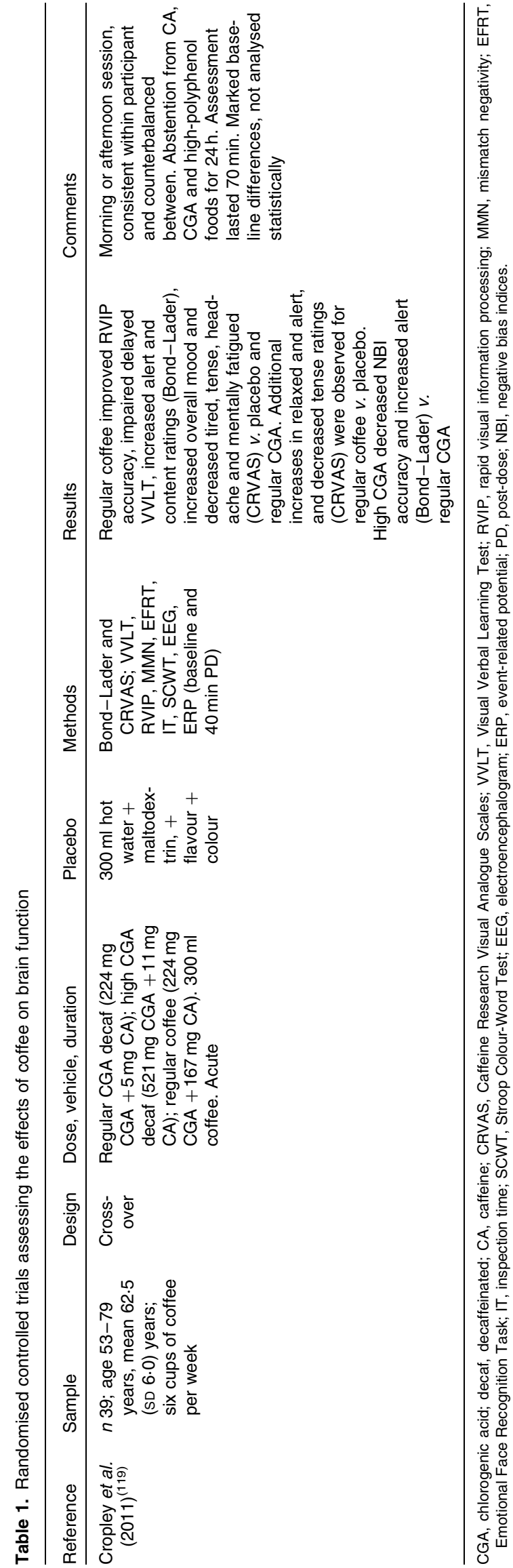


(the difference between responses to sad and happy faces). However, as these effects were only observed in comparison with regular 'CGA decaffeinated' they allow us to isolate CGA as the compound responsible for these effects. The effects of caffeinated coffee in this study may be indicative of a synergistic effect between caffeine and other components within coffee, including CGA. However, without the inclusion of a caffeine-only arm it is not possible to ascertain this. Although findings from this pilot study combined with epidemiological data provide a suggestion that non-caffeine components within coffee may have some behavioural effects in human subjects, the evidence as it stands is far from convincing, particularly given the lack of effects of CGA on cognition. The observation that effects of high CGA are only apparent when compared with low CGA, as opposed to placebo, would indicate that at lower levels CGA is actually detrimental to those parameters affected. However, evidence that caffeinated and decaffeinated coffee, as well as CGA, are able to prevent apoptosis induced by $\mathrm{H}_{2} \mathrm{O}_{2}$ and increase NADPH:quinine oxidoreductase 1 , which is regulated by the Nrf2 pathway, suggests that neuroprotection via antioxidant mechanisms is a strong possibility ${ }^{(120)}$. CGA isolated from other sources has also demonstrated similar protective effects against oxidative stress ${ }^{(121,122)}$. Further support for antioxidant properties of CGA comes from ex vivo work showing its ability to reduce malondialdehyde in the hippocampus and frontal cortex. Short-term behavioural benefits have also been demonstrated in a rodent scopolamine challenge model with associated acetylcholinesterase inhibition observed in vitro and ex vivo ${ }^{(83)}$. Further work directed at the effects of this compound in humans as well as research into other coffee components, such as the diterpenes kahweol and cafestol, which also have demonstrated antioxidant ${ }^{(123,124)}$ as well as anti-inflammatory properties $^{(125,126)}$, is needed.

\section{Tea (Camellia sinensis)}

Perhaps surprisingly, the effects of tea on cognition and mood have received far greater attention than coffee, with a number of studies comparing the effects of tea with coffee and thus also providing some information on the effects of coffee. In one of several open-label studies Quinlan et al $^{(127)}$ investigated the effects of $100 \mathrm{mg}$ caffeine in differing vehicles (tea, coffee, water) on mood and physiological measures. Tea resulted in greater skin temperature increases as compared with coffee or water, suggesting greater vasodilation as a consequence of flavonoid content. This effect was not replicated when explored further by comparing tea containing 37.5 and $75 \mathrm{mg}$ caffeine with coffee containing 75 and $150 \mathrm{mg}$, and hot water or no drink. The only significant effect of vehicle was greater lowering of sedation ratings following coffee than tea ${ }^{(7)}$. Significant increases in critical flicker fusion following $100 \mathrm{mg}$ caffeine in tea are not demonstrated following the same dose in coffee ${ }^{(128)}$, an effect replicated following $75 \mathrm{mg}$ caffeine, along with a differential effect on choice reaction time in favour of coffee ${ }^{(117)}$. However, sedation ratings were decreased by caffeine irrespective of vehicle, representing a failure to replicate earlier findings ${ }^{(128)}$.

In a naturalistic study at high altitude, Scott et al. ${ }^{(129)}$ demonstrated that tea drinking was associated with lower fatigue ratings in regular tea drinkers. More recently De Bruin et al. ${ }^{(130)}$ described two randomised, controlled trials of black tea as compared with placebo tea. In the first of these, $1040 \mathrm{mg}$ tea solids (containing $100 \mathrm{mg}$ caffeine and $46 \mathrm{mg}$ L-theanine) were shown to significantly improve intersensory attention and performance of a switch task. Participants also felt more alert and less calm following tea. In a second study, these effects on the switch task and alertness ratings were replicated following $760 \mathrm{mg}$ tea solids ( $60 \mathrm{mg}$ caffeine, $24 \mathrm{mg}$ L-theanine). The lack of effects on 'calm' and intersensory attention in the second study may be the result of the slightly lower caffeine and L-theanine levels but differences in the times of testing and the tea employed make it difficult to assess this. The finding of reduced 'calm' in study 1 is in keeping with the stimulant effects of caffeine but is difficult to reconcile with the generally promoted relaxed alertness induced by tea.

Although the preceding studies are useful in demonstrating ecologically valid effects of tea drinking, they do not allow for ascertaining the contribution of non-caffeine components to these effects. The earlier studies also face the obvious problems associated with open-label trials, particularly when conducted by, or in collaboration with, tea manufacturers. In an attempt to overcome these issues, Steptoe et al. ${ }^{(131)}$ explored the effects of chronic tea administration (containing $72 \mathrm{mg}$ caffeine) as compared with a caffeine-matched placebo in terms of effects on stress responsivity and recovery. The findings showed that tea was able to attenuate the effects of stress on platelet activation and cortisol levels, as well as increasing 'relaxation' ratings, relative to placebo. The use of a caffeinated placebo in this study allows for the conclusion that components within tea are able to modulate the effects of caffeine and/or produce direct 'anti-stress' effects; an assertion not possible when assessing caffeinated tea against a non-caffeinated placebo (as above). Support for a direct effect of non-caffeine components within tea comes from Henry \& Stephens-Larson ${ }^{(132)}$ who found that hypertension in mice exposed to 3-5 months of psychosocial stress was significantly reduced by chronic administration of decaffeinated green tea as compared with water. With the exception of the latter study ${ }^{(131)}$, human research on tea to date has contributed little to our knowledge regarding its behavioural effects beyond that attributed to caffeine; studies demonstrating differences between tea and coffee are inconsistent and do not allow for assessment of which components are involved in any differential effects of these two caffeine sources. 
Two of the main components studied regarding potential bioactivity in tea are covered in the following sub-sections.

$L$-Theanine. $\quad$ L-Theanine ( $\gamma$-glutamylethylamide) is found almost uniquely in tea and is one of the predominant amino acids present, making up between 1 and $2 \%$ of the dry weight, resulting in about $25-60 \mathrm{mg}$ L-theanine per $200 \mathrm{ml}$ cup of tea. L-Theanine has been used in Asia for centuries in order to produce feelings of relaxation ${ }^{(133)}$, but it is only recently that human studies exploring this effect have been conducted. A number of studies have demonstrated electroencephalogram (EEG) modulation following L-theanine administration. Kobayashi et al. ${ }^{(134)}$ found that $200 \mathrm{mg}$ L-theanine led to increased alpha waves in the occipital and parietal regions of the brain within $40 \mathrm{~min}$ of ingestion when administered to resting participants, which the authors suggest is indicative of 'relaxation' without 'drowsiness'. Nobre et al. ${ }^{(135)}$ assessed the effect of $50 \mathrm{mg}$ L-theanine on resting EEG activity in healthy young volunteers and found significantly increased alpha activity as compared with placebo. However, the ability of a compound to modulate alpha activity does not unequivocally confirm anxiolytic properties, as similar findings have been demonstrated with non-anxiolytics ${ }^{(84)}$. L-Theanine has also been shown to reduce background alpha activity in the parieto-occipital region during performance of a demanding task whilst increasing attentionrelated (anticipatory) alpha activity ${ }^{(136)}$. This reduction in background alpha activity was replicated in a similar study exploring effects during a visuospatial task but the effect on anticipatory alpha activity was not ${ }^{(137)}$. However, when considering the effects of $100 \mathrm{mg}$ L-theanine and $50 \mathrm{mg}$ caffeine both alone and in combination, Foxe et $a l^{(138)}$ failed to find any effect of L-theanine on alpha band activity during performance of a sustained attention task when administered in isolation. One possible explanation for the differential results produced by Foxe et $a .^{(138)}$ is the use of largely non-caffeine consumers and non-tea drinkers, with only two participants drinking tea and at a level of only one cup per $\mathrm{d}$.

Physiological and subjective responses to L-theanine also suggest an anxiolytic effect. Kimura et al. ${ }^{(139)}$ observed that heart rate, salivary IgA and the subjective perception of stress were lower following L-theanine as compared with placebo in response to a 20 min mental arithmetic task. A $250 \mathrm{mg}$ dose of L-theanine has also been shown to slow reaction time on a visual probe task, indicating reduced anxiety in healthy young volunteers ${ }^{(140)}$. In contrast, Lu et al. ${ }^{(141)}$ were only able to demonstrate the relaxant effects of $200 \mathrm{mg}$ L-theanine, as measured by the 'tranquil-troubled' item of the Bond-Lader visual analogue scales, during resting conditions. This effect was not apparent when anxiety was induced through the anticipation of electric shock. Despite the assertion that L-theanine produces 'relaxation without drowsiness', studies assessing the behavioural effects of L-theanine have demonstrated decrements in performance. Impairment has taken the form of a reduction in the number of serial sevens subtractions completed (as well as increasing subjective headache ratings) ${ }^{(142)}$ and slowed reaction time in response to an auditory $\operatorname{task}^{(136)}$. However, most studies have failed to show any behavioural effects of L-theanine in isolation ${ }^{(137,142-144)}$, with only one study to date demonstrating a positive effect; Foxe et al. ${ }^{(138)}$ demonstrated a significant reduction in omission and commission errors on a sustained attention to response inhibition task following $100 \mathrm{mg}$ L-theanine as compared with placebo.

It has been suggested that the most beneficial effects of L-theanine are observed when administered in combination with caffeine, due to a modulation of caffeine's stimulatory effects. For instance, Haskell et al. ${ }^{(142)}$ reported a number of effects following a combination of $250 \mathrm{mg}$ L-theanine and $150 \mathrm{mg}$ caffeine that were not apparent when each compound was administered alone. Improvements included increased speed on several tasks (simple reaction time, delayed word recognition, numeric working memory) and improved sentence verification accuracy. Participants also rated themselves as being more 'alert' and less 'tired'. Combining $250 \mathrm{mg}$ caffeine with $200 \mathrm{mg}$ L-theanine resulted in the abolition of systolic and diastolic blood pressure increases seen following administration of caffeine alone ${ }^{(140)}$. A combination of $100 \mathrm{mg}$ L-theanine and $50 \mathrm{mg}$ caffeine was also capable of improving performance accuracy (as measured by increased hit rate and target discriminability) and reducing overall tonic (background) alpha power ${ }^{(143)}$, as well as simultaneously improving speed and accuracy on an attention-switching task at $60 \mathrm{~min}$ post-dose and performance on a memory task at 60 and $90 \mathrm{~min}$ post-dose ${ }^{(144)}$. Similar dose levels of L-theanine $(97 \mathrm{mg}$ ) in combination with caffeine ( $40 \mathrm{mg}$ ) improved accuracy on a switch task with a trend towards faster responses on an intersensory task of attention ${ }^{(145)}$ This combination also improved accuracy on a switch task as well as increasing subjective alertness and reducing task-induced fatigue ${ }^{(146)}$. Foxe et al ${ }^{(138)}$ also found a significant reduction in omission and commission errors on the sustained attention to response inhibition task following $100 \mathrm{mg}$ L-theanine combined with $50 \mathrm{mg}$ caffeine, as well as attenuation in tonic alpha activity. However, no synergistic effect was observed with the effect of the combination being equivocal to that seen with caffeine alone.

With the exception of an anxiolytic effect, these findings demonstrate very few positive effects of L-theanine in isolation; in fact, the over-riding conclusion is that L-theanine impairs attention. Although positive outcomes have been indicated by those studies that have explored its effects in combination, the majority do not allow delineation of effects of this combination over and above those of caffeine alone. Of those studies that do allow this distinction $^{(138,140,142)}$, there is a lack of interaction effects or findings are shown to be equivocal between those of the combination and those of caffeine in isolation ${ }^{(138)}$. Studies of L-theanine, either in isolation or in combination 
with caffeine, have also failed to explore the longer-term effects. Given the habitual nature of tea drinking, it is necessary for further work to be directed at ascertaining the effects of chronic consumption of L-theanine. The same observation can also be applied to EGCG research, covered in the following section.

Epigallocatechin gallate. Only two intervention studies to date have assessed the effects of EGCG on neural activity and cognitive performance in humans. In a randomised, double-blind, placebo-controlled cross-over study Wightman et al. ${ }^{(147)}$ assessed CBF in the frontal cortex utilising near-IR spectroscopy. A group of twentyseven healthy, young participants performed a range of cognitive tasks at baseline and then again $45 \mathrm{~min}$ after consumption of 135 or $270 \mathrm{mg}$ pure EGCG. The results showed that, during the post-dose task performance period, the administration of $135 \mathrm{mg}$ EGCG resulted in reduced $\mathrm{CBF}$ in the frontal cortex as indexed by significantly lower concentrations of both oxygenated and total $\mathrm{Hb}$, in comparison with placebo. No effects were observed on cognitive performance. This reduction in CBF suggests that EGCG was exerting a vasoconstrictive effect, but in the absence of any modulation of behavioural parameters, the identification of a positive or negative influence of this effect on neurocognitive function is difficult. On the most simplistic level, optimal performance should require increased delivery of blood, and therefore metabolic substrates, during neuronal demand. However, it is also possible that this reduction in $\mathrm{CBF}$ with no negative impact on performance is indicative of increased neural efficiency. Scholey et al. ${ }^{(148)}$ examined the effects of $300 \mathrm{mg}$ Teavigo on electrical brain activity, as assessed through resting-state EEG, and mood in healthy human participants. EGCG increased cerebral activity in the form of alpha, beta and theta waves measured $180 \mathrm{~min}$ postconsumption. Ratings of 'calmness' were also increased at the same time and 'stress' ratings were significantly decreased. Cognitive and cardiovascular functioning effects from this study are, as yet, unpublished.

The paucity of data available relating to the behavioural effects of EGCG makes it impossible to assess its efficacy at the present time. Based upon human data to date, there is very little evidence of behavioural effects, with the exception of modulation of subjective ratings pertaining to 'relaxation' in one study ${ }^{(148)}$. This effect aligns with the common perception of tea as relaxing but is contrary to previous data from tea as a whole showing decreased calmness ${ }^{(130)}$; although it should be noted that this reduction in calmness has not been replicated. The finding of increased cerebral activity ${ }^{(148)}$ would seem to be contradictory to the observation of decreased $\mathrm{CBF}^{(147)}$, but it should be noted that increased cerebral activity was observed following more than double the dose shown to decrease CBF and this may well represent opposing effects at different doses.

Randomised controlled trials of tea are summarised in Table 2 .

\section{Cocoa (Theobroma cacao L)}

Research into effects of cocoa was first triggered by observations of a lack of blood pressure increases with age, and the virtual non-existence of hypertension in Kuna Indians living off the coast of Panama, who drank large quantities of cocoa on a daily basis. These effects were attributed to cocoa flavan-3-ols and a number of studies have demonstrated increased peripheral blood flow following flavan-3-ol-rich cocoa (for example, Engler et al. ${ }^{(70)}$, Heiss et al. ${ }^{(74)}$, Fisher et $a l .{ }^{(149)}$ and Flammer et al. $\left.{ }^{(150)}\right)$. However, it is also possible that theobromine, a methylxanthine present in cocoa, may have a role to play in these effects. Crews et al. ${ }^{(151)}$ compared the effects of cocoa, in the form of $37 \mathrm{~g}$ dark chocolate (containing about $11 \mathrm{~g}$ cocoa $(397 \mathrm{mg} / \mathrm{g}$ total proanthocyanidins)) plus $237 \mathrm{ml}$ cocoa beverage (containing $11 \mathrm{~g}$ cocoa (357 mg/g total proanthocyanidins)), with placebo products over a 6 -week intervention period in ninety cognitively intact elderly participants. Despite the older age of participants in this study and the long intervention period, effects on cognition were not apparent. One possible explanation for this lack of effects is the use of neuropsychological tasks that may not be sensitive enough to detect small changes in cognition. Alternatively, the lack of significant benefits may indicate that cognitive effects are only apparent acutely. This suggestion is supported by findings from Field et al ${ }^{(152)}$ who demonstrated improvements to visual contrast sensitivity (as assessed by reading numbers that became progressively more similar in luminance to their background) and the time to detect motion direction, following dark chocolate $(720 \mathrm{mg}$ cocoa flavan-3-ols; $38 \mathrm{mg}$ caffeine; $222 \mathrm{mg}$ theobromine) as compared with white chocolate. This study also demonstrated improvements to a visual spatial memory task following dark chocolate. Although both studies demonstrate the ability of cocoa to improve cognition, it is difficult to draw firm conclusions regarding the mechanism of action of these effects.

Studies covering the effects of theobromine and cocoa flavan-3-ols that allow some delineation of effects of cocoa make up the next two sub-sections of the present review.

Theobromine. In the first of only four studies to date that have explored the effects of theobromine on behaviour, Mumford et al. ${ }^{(153)}$ failed to find group subjective effects of $560 \mathrm{mg}$ of theobromine. However, four of the seven participants were able to discriminate this dose of theobromine from placebo. Smit et al. ${ }^{(154)}$ administered methylxanthine levels equivalent to that found in a $50 \mathrm{~g}$ bar of dark chocolate $(250 \mathrm{mg}$ theobromine, $19 \mathrm{mg}$ caffeine) in two different encapsulated forms - cocoa powder, or theobromine + caffeine only. These active treatments were compared with placebo in terms of effects on mood and performance at 1 and $2 \mathrm{~h}$ post-intake. Both active treatments were observed to reduce simple reaction 
Table 2. Randomised controlled trials assessing the effects of tea on brain function

\begin{tabular}{|c|c|c|c|c|c|c|c|}
\hline Reference & Sample & Design & $\begin{array}{l}\text { Dose, vehicle, } \\
\text { duration }\end{array}$ & Placebo & Methods & Results & Comments \\
\hline \multicolumn{8}{|l|}{ Tea } \\
\hline $\begin{array}{l}\text { De Bruin et al. } \\
(2011) \text { : study } \\
1^{(130)}\end{array}$ & $\begin{array}{l}n \text { 26; mean age } \\
30.7 \\
(\text { SD } 11 \cdot 2) \\
\text { years; 306.4 } \\
\text { (SD 148.6) mg } \\
\text { CA/d }\end{array}$ & Cross-over & $\begin{array}{l}520 \mathrm{mg} \text { tea } \\
\text { solids }(50 \mathrm{mg} \\
\mathrm{CA} ; 23 \mathrm{mg} \\
\mathrm{L}-\mathrm{T}) .200 \mathrm{ml} \\
\text { tea. Acute at } \\
0 \text { and } 50 \mathrm{~min}\end{array}$ & $\begin{array}{l}200 \mathrm{ml} \\
\text { boiled } \\
\text { water }+ \\
\text { colour }+ \\
\text { flavour }\end{array}$ & $\begin{array}{l}\text { Task switching, intersensory atten- } \\
\text { tion, Bond-Lader VAS (baseline; } \\
10 \text { and } 60 \text { min PD) }\end{array}$ & $\begin{array}{l}\text { Tea improved speed and accuracy of } \\
\text { intersensory attention and increased } \\
\text { accuracy of task switching. Alert rat- } \\
\text { ings increased and calm ratings } \\
\text { decreased following tea }\end{array}$ & $\begin{array}{l}\text { Session commenced } \\
\text { at } 12.00 \text { hours fol- } \\
\text { lowing normal } \\
\text { breakfast and } \\
\text { water }\end{array}$ \\
\hline $\begin{array}{l}\text { De Bruin et al. } \\
(2011): \text { study } \\
2^{(130)}\end{array}$ & $\begin{array}{l}n \text { 32; mean age } \\
30 \cdot 3 \\
(\text { SD 10.1) } \\
\text { years; 280.1 } \\
(\text { SD 142.2) mg } \\
\text { CA/d }\end{array}$ & Cross-over & $\begin{array}{l}380 \mathrm{mg} \text { tea } \\
\text { solids }(30 \mathrm{mg} \\
\mathrm{CA} ; 12 \mathrm{mg} \\
\text { L-T). } 200 \mathrm{ml} \\
\text { tea. Acute at } \\
0,40 \text { and } \\
80 \mathrm{~min}\end{array}$ & $\begin{array}{l}200 \mathrm{ml} \\
\text { boiled } \\
\text { water }+ \\
\text { colour }+ \\
\text { flavour }\end{array}$ & $\begin{array}{l}\text { Task switching, intersensory atten- } \\
\text { tion, Bond-Lader VAS (baseline; } \\
10,50 \text { and } 90 \text { min PD) }\end{array}$ & $\begin{array}{l}\text { Tea improved accuracy of task switch- } \\
\text { ing and increased alert ratings }\end{array}$ & As study 1 \\
\hline $\begin{array}{l}\text { Steptoe et al. } \\
(2007)^{(131)}\end{array}$ & $\begin{array}{l}\text { n } 75 \text {; age } 18-55 \\
\text { (mean } 33 \cdot 2) \\
\text { years; male tea } \\
\text { drinkers }\end{array}$ & $\begin{array}{l}\text { Parallel } \\
\text { groups }\end{array}$ & $\begin{array}{l}1050 \mathrm{mg} \text { tea } \\
(72 \mathrm{mg} \mathrm{CA}) \text {. } \\
\text { Apple/lemon- } \\
\text { flavour } \\
\text { sachet in hot } \\
\text { water } \times 4 \\
\text { per d. } 6 \\
\text { weeks }\end{array}$ & $\begin{array}{l}\text { Flavour } \\
\text { and CA } \\
\text { matched } \\
\text { powder }\end{array}$ & $\begin{array}{l}\text { On day } 1 \text { and day } 43 \\
\text { Tasks: } 3 \text { min socially evaluated } \\
\text { speech; } 5 \text { min mirror-tracing } \\
\text { Stress measures (all assessed } \\
\text { pre-task): BP and HR (during and } \\
25-30 \text { min post-tasks); stress rat- } \\
\text { ings (immediately and } 30 \text { min } \\
\text { post-tasks); relaxation ratings } \\
\text { ( } 30 \text { min post-tasks); platelet } \\
\text { monocyte, neutrophil and leuco- } \\
\text { cyte aggregates ( } 10 \text { min post- } \\
\text { task); salivary cortisol } \\
\text { (1, } 15,30 \text { and } 50 \text { min post-task) }\end{array}$ & $\begin{array}{l}\text { Tea reduced platelet activation (mono- } \\
\text { cyte, neutrophil and leucocyte) and } \\
\text { cortisol ( } 50 \text { min PD) and increased } \\
\text { 'relaxation' }\end{array}$ & $\begin{array}{l}\text { Allocated intervention } \\
\text { consumed on } \\
\text { morning of PD } \\
\text { testing }\end{array}$ \\
\hline \multicolumn{8}{|c|}{$(1,15,50$ dinu 50 mint pust-iask) } \\
\hline $\begin{array}{l}\text { Einother et al. } \\
(2010)^{(145)}\end{array}$ & $\begin{array}{l}\text { n 29; age 18-45 } \\
\text { (mean 30.6, SD } \\
\text { 8.9) years; } \\
11.7 \text { (SD 6.7) } \\
\text { CA drinks per } \\
\text { week }\end{array}$ & Cross-over & $\begin{array}{l}97 \mathrm{mg} \\
\mathrm{L}-\mathrm{T}+40 \mathrm{mg} \\
\mathrm{CA} . \text { Iced tea } \\
\text { powder } \\
\quad+500 \mathrm{ml} \\
\text { water. Acute }\end{array}$ & $\begin{array}{l}\text { Iced tea } \\
\text { powder } \\
\quad+500 \mathrm{ml} \\
\text { water }\end{array}$ & $\begin{array}{l}\text { Intersensory attention task, switch } \\
\text { task, Bond-Lader VAS (baseline, } \\
10 \text { and } 60 \text { min PD) }\end{array}$ & $\begin{array}{l}\mathrm{L}-\mathrm{T}+\mathrm{CA} \text { increased correct responses } \\
\text { on switch task }\end{array}$ & \\
\hline $\begin{array}{l}\text { Foxe et al. } \\
(2012)^{(138)}\end{array}$ & $\begin{array}{l}\text { 21; age } 18-40 \\
\text { (mean } 26) \\
\text { years; } 0-3 \\
\text { cups coffee } \\
\text { and/or tea/d }\end{array}$ & Cross-over & $\begin{array}{l}100 \mathrm{mg} \mathrm{L-T} \\
50 \mathrm{mg} \mathrm{CA} \\
100 \mathrm{mg} \\
\text { L-T }+50 \mathrm{mg} \\
\text { CA. } 200 \mathrm{ml} \\
\text { cool water. } \\
\text { Acute }\end{array}$ & $\begin{array}{l}200 \mathrm{ml} \mathrm{cool} \\
\text { water }\end{array}$ & $\begin{array}{l}\text { EEG activity during SART } \\
(25-185 \mathrm{~min} P D)\end{array}$ & $\begin{array}{l}\text { All active treatments reduced SART } \\
\text { error rates. CA and L-T }+C A \\
\text { reduced alpha-band activity }\end{array}$ & \\
\hline $\begin{array}{l}\text { Giesbrecht et al. } \\
(2010)^{(146)}\end{array}$ & $\begin{array}{l}n \text { 44; age } 18-34 \\
\text { (mean } 21.2, \mathrm{SD} \\
3.2 \text { ) years; } 173 \\
\text { (SD 86.8) mg } \\
\text { CA/d; 39.7 (SD } \\
25.9) \mathrm{mg} \mathrm{L-T/d}\end{array}$ & Cross-over & $\begin{array}{l}97 \mathrm{mg} \\
\mathrm{L}-\mathrm{T}+40 \mathrm{mg} \\
\mathrm{CA} . \text { Iced tea } \\
\text { powder } \\
+500 \mathrm{ml} \\
\text { water. Acute }\end{array}$ & $\begin{array}{l}\text { Iced tea } \\
\quad \text { powder } \\
+500 \mathrm{ml} \\
\text { water }\end{array}$ & $\begin{array}{l}\text { CRT, VST, EMRT, attention-switch- } \\
\text { ing task, Task demand rating } \\
\text { scale, Bond-Lader VAS, SBP, } \\
\text { DBP, HR (baseline; } 20 \text { and } \\
70 \text { min PD) }\end{array}$ & $\begin{array}{l}\text { L-T + CA improved attention-switching } \\
\text { accuracy, reduced tiredness and } \\
\text { increased alertness and SBP }\end{array}$ & \\
\hline
\end{tabular}




\begin{tabular}{|c|c|c|c|c|c|c|c|}
\hline Reference & Sample & Design & $\begin{array}{l}\text { Dose, vehicle, } \\
\text { duration }\end{array}$ & Placebo & Methods & Results & Comments \\
\hline $\begin{array}{l}\text { Gomez- } \\
\text { Ramirez et al. } \\
(2007)^{(136)}\end{array}$ & $\begin{array}{l}n 15 ; \text { age } 18-36 \\
\quad \text { (mean } 27 \cdot 8, \mathrm{SD} \\
6 \cdot 5) \text { years }\end{array}$ & Cross-over & $\begin{array}{l}250 \mathrm{mg} \mathrm{L-T} \text {. } \\
200 \mathrm{ml} \\
\text { water. Acute }\end{array}$ & $\begin{array}{l}200 \mathrm{ml} \\
\text { water }\end{array}$ & $\begin{array}{l}\text { EEG activity during intersensory } \\
\text { (auditory-visual) attentional cuing } \\
\text { task }\end{array}$ & $\begin{array}{l}\text { L-T increased RT during unisensory- } \\
\text { auditory and multisensory-auditory } \\
\text { stimuli. During task performance, L-T } \\
\text { reduced overall background (tonic) } \\
\text { alpha levels but led to an increase in } \\
\text { cue (attention)-related anticipatory } \\
\text { (phasic) alpha levels }\end{array}$ & \\
\hline $\begin{array}{l}\text { Gomez- } \\
\text { Ramirez et al. } \\
(2009)^{(137)}\end{array}$ & $\begin{array}{l}n 13 ; \text { mean age } \\
23.5(\mathrm{SD} 3.25) \\
\text { years }\end{array}$ & Cross-over & $\begin{array}{l}250 \mathrm{mg} \mathrm{L-T} \text {. } \\
200 \mathrm{ml} \\
\text { water. Acute }\end{array}$ & $\begin{array}{l}200 \mathrm{ml} \\
\text { water }\end{array}$ & $\begin{array}{l}\text { EEG activity during visuospatial } \\
\text { attention task }\end{array}$ & $\begin{array}{l}\text { During task performance L-T reduced } \\
\text { background (tonic) alpha activity over } \\
\text { the right parieto-occipito region and } \\
\text { led to a reduction in overall cue } \\
\text { (attention)-related anticipatory (pha- } \\
\text { sic) alpha levels }\end{array}$ & \\
\hline $\begin{array}{l}\text { Haskell et al. } \\
(2008)^{(142)}\end{array}$ & $\begin{array}{l}n \text { 24; age } 18-34 \\
\quad \text { mean } 21 \cdot 3) \\
\text { years }\end{array}$ & Cross-over & $\begin{array}{l}250 \mathrm{mg} \mathrm{L}-\mathrm{T} ; \\
150 \mathrm{mg} \text { CA; } \\
250 \mathrm{mg} \\
\mathrm{L}- \\
\mathrm{T}+150 \mathrm{mg} \\
\text { CA. } 250 \mathrm{ml} \\
\text { iced tea } \\
\text { drink. Acute }\end{array}$ & $\begin{array}{l}250 \mathrm{ml} \text { iced } \\
\text { tea drink } \\
\text { (no } \\
\text { active } \\
\text { tea ingre- } \\
\text { dients) }\end{array}$ & $\begin{array}{l}\text { IWR, SRT, DV, CRT, RVIP, SWM, } \\
\text { LR, NWM, DWR, WRec, PRec, } \\
\text { SV, S3, S7, CRVAS, Bond- } \\
\text { Lader VAS (baseline; } 30 \text { and } \\
90 \text { min PD) }\end{array}$ & $\begin{array}{l}\text { CA reduced mental fatigue, increased } \\
\text { DV speed and improved RVIP accu- } \\
\text { racy. CA + L-T increased alertness, } \\
\text { reduced tiredness, headache } \\
\text { (90 min) and mental fatigue. CA + L- } \\
\text { T reduced SRT and NWM reaction } \\
\text { time, and improved RVIP and SV } \\
\text { accuracy. At } 90 \text { min L-T increased } \\
\text { headache ratings and impaired S7 } \\
\text { accuracy }\end{array}$ & \\
\hline $\begin{array}{l}\text { Kelly et al. } \\
(2008)^{(143)}\end{array}$ & $\begin{array}{l}n \text { 16; age } 21-40 \\
\text { (mean } 27 \cdot 5 \text { ) } \\
\text { years; } 3 \cdot 7 \text { cups } \\
\text { tea per week } \\
\text { and } 3 \cdot 8 \text { cups } \\
\text { coffee per } \\
\text { week }\end{array}$ & Cross-over & $\begin{array}{l}100 \mathrm{mg} \mathrm{L}-\mathrm{T} ; \\
50 \mathrm{mg} \mathrm{CA} \\
100 \mathrm{mg} \\
\mathrm{L}-\mathrm{T}+50 \mathrm{mg} \\
\text { CA. } 100 \mathrm{ml} \\
\text { water. Acute }\end{array}$ & $\begin{array}{l}100 \mathrm{ml} \\
\text { water }\end{array}$ & $\begin{array}{l}\text { EEG activity during visuospatial } \\
\text { attention task ( } 30 \mathrm{~min} P D)\end{array}$ & $\begin{array}{l}\text { L-T + CA improved hit rate and target } \\
\text { discriminability and reduced tonic } \\
\text { alpha-levels. CA improved target dis- } \\
\text { criminability }\end{array}$ & $\begin{array}{l}\text { Participants attended } \\
\text { the laboratory } \\
\text { between } 09.00 \text { and } \\
12.00 \text { hours }\end{array}$ \\
\hline $\begin{array}{l}\text { Kimura et al. } \\
(2007)^{(139)}\end{array}$ & $\begin{array}{l}\text { Males; } n 12 ; \text { age } \\
20-25 \text { (mean } \\
21 \cdot 5, \text { SD } 1 \cdot 38) \\
\text { years }\end{array}$ & Cross-over & $\begin{array}{l}200 \mathrm{mg} \mathrm{L-T.} \\
100 \mathrm{ml} \\
\text { water. Acute }\end{array}$ & $\begin{array}{l}100 \mathrm{ml} \\
\text { water }\end{array}$ & $\begin{array}{l}\text { Mental arithmetic 'stress task' } \\
\text { (0 and } 20 \text { min PD); Subjective } \\
\text { stress scale, STAI-Y1 and s-IgA } \\
\text { (baseline; } 20,30 \text { and } 40 \text { min PD). } \\
\text { ECG to assess HR and HRV } \\
\text { measured throughout session } \\
\text { until } 60 \text { min PD }\end{array}$ & $\begin{array}{l}\text { L-T reduced STAI anxiety score, sub- } \\
\text { jective stress responses, HR and } \\
\text { S-IgA following mental arithmetic } \\
\text { 'stress task' }\end{array}$ & \\
\hline $\begin{array}{l}\text { Kobayashi et al. } \\
(1998)^{(134)}\end{array}$ & $\begin{array}{l}\text { Females; high } \\
\text { anxiety }(n 4) \\
\text { and low anxiety } \\
(n \text { 4); age } 18- \\
22 \text { years }\end{array}$ & $\begin{array}{l}\text { Parallel } \\
\text { groups }\end{array}$ & $\begin{array}{l}50 \mathrm{mg} \mathrm{L}-\mathrm{T} ; \\
200 \mathrm{mg} \text { L-T. } \\
100 \mathrm{ml} \\
\text { water. Acute }\end{array}$ & Water & EEG activity at rest for $60 \mathrm{~min}$ & $\begin{array}{l}200 \mathrm{mg} \mathrm{L}-\mathrm{T} \text { increased alpha waves in } \\
\text { occipital and parietal regions } 40 \mathrm{~min} \\
\text { after ingestion }\end{array}$ & $\begin{array}{l}\text { Anxiety levels deter- } \\
\text { mined by MAS, } \\
\text { high-anxiety group } \\
\text { grade I; low- } \\
\text { anxiety group } \\
\text { grade V }\end{array}$ \\
\hline
\end{tabular}




\begin{tabular}{|c|c|c|c|c|c|c|c|}
\hline Reference & Sample & Design & $\begin{array}{l}\text { Dose, vehicle, } \\
\text { duration }\end{array}$ & Placebo & Methods & Results & Comments \\
\hline $\begin{array}{l}\text { Lu et al. } \\
(2004)^{(141)}\end{array}$ & $\begin{array}{l}n \text { 16; age } 18-34 \\
\text { years; males } \\
(n 12) \text { mean } \\
\text { age 24.8 (SD } \\
5.4) \text { years; } \\
\text { females } \\
(n \text { 4) mean age } \\
29.0 \text { (SD 1.4) } \\
\text { years }\end{array}$ & Cross-over & $\begin{array}{l}200 \mathrm{mg} \mathrm{L}-\mathrm{T} ; \\
1 \mathrm{mg} \text { ALP. } \\
\text { Acute }\end{array}$ & $0 \mathrm{mg} \mathrm{L-T}$ & $\begin{array}{l}\text { BDI-II (baseline); AA (electric } \\
\text { shock) task and relaxed con- } \\
\text { dition, STAI-Y1, STAI-Y2, BAI, } \\
\text { Bond-Lader VAS (baseline, 2.5, } \\
3.5 \text { and 5h PD) }\end{array}$ & $\begin{array}{l}\text { L-T reduced subjective anxiety } \\
\text { (Bond-Lader measure) compared } \\
\text { with ALP and placebo in relaxed con- } \\
\text { dition }\end{array}$ & \\
\hline $\begin{array}{l}\text { Nobre et al. } \\
(2008)^{(135)}\end{array}$ & $n 35$ & $\begin{array}{l}\text { Parallel } \\
\text { groups }\end{array}$ & $\begin{array}{l}0.5 \mathrm{mg} \mathrm{L}-\mathrm{T} / \mathrm{kg} \\
\text { body weight } \\
\text { in tea infu- } \\
\text { sion. Acute }\end{array}$ & $\begin{array}{l}100 \mathrm{ml} \mathrm{cool} \\
\text { water }\end{array}$ & $\begin{array}{l}\text { EEG activity at rest, eyes closed } \\
\text { (baseline; 45, 60, 75, } 90 \text { and } \\
105 \text { min PD) }\end{array}$ & $\begin{array}{l}\text { L-T led to linear increase in alpha- } 1 \\
\text { band activity over time }\end{array}$ & \\
\hline $\begin{array}{l}\text { Owen et al. } \\
(2008)^{(144)}\end{array}$ & $\begin{array}{l}\text { 27; mean age } \\
28.3 \text { (SD } 5 \cdot 3 \text { ) } \\
\text { years; } 9 \cdot 6 \text { (SD } \\
5.5 \text { ) servings } \\
\text { CA per week }\end{array}$ & Cross-over & $\begin{array}{l}50 \mathrm{mg} \mathrm{CA} \\
100 \mathrm{mg} \\
\mathrm{L}-\mathrm{T}+50 \mathrm{mg} \\
\text { CA. } 250 \mathrm{ml} \\
\text { iced tea. } \\
\text { Acute }\end{array}$ & $\begin{array}{l}250 \mathrm{ml} \text { iced } \\
\text { tea (tea } \\
\text { powder } \\
\text { and CA } \\
\text { removed) }\end{array}$ & $\begin{array}{l}\text { WRec, RVIP, CFF, attention-switch- } \\
\text { ing task, Bond-Lader VAS } \\
\text { (baseline, } 60 \text { and } 90 \text { min PD) }\end{array}$ & $\begin{array}{l}\text { L-T + CA improved WRec (60 and } \\
90 \text { min) and improved speed and } \\
\text { accuracy on attention switching } \\
\text { (60 min). CA improved accuracy on } \\
\text { attention switching ( } 90 \text { min) and } \\
\text { increased alertness }\end{array}$ & \\
\hline $\begin{array}{l}\text { Rogers et al. } \\
(2008)^{(140)}\end{array}$ & $\begin{array}{l}\text { 48; age } 18-28 \\
\text { (mean } 20.5, \mathrm{SD} \\
2 \cdot 0) \text { years. } 116 \\
\text { (SD } 81) \mathrm{mg} \\
\mathrm{CA} / \mathrm{d}\end{array}$ & $\begin{array}{l}\text { Parallel } \\
\text { groups }\end{array}$ & $\begin{array}{l}250 \mathrm{mg} \mathrm{CA} \\
\text { (capsule); } \\
200 \mathrm{mg} \text { L-T } \\
\text { (peach-fla- } \\
\text { vour drink); } \\
250 \mathrm{mg} \mathrm{CA} \\
\text { +200 mg } \\
\text { L-T. Acute }\end{array}$ & $\begin{array}{l}\text { CA }=\text { corn- } \\
\text { flour; } \\
\text { L-T }= \\
\text { placebo } \\
\text { peach- } \\
\text { flavour } \\
\text { drink }\end{array}$ & $\begin{array}{l}\text { Visual probe task ( } 30 \text { or } 50 \text { min } \\
\text { PD); STAI-Y2, DASS-trait (0 min } \\
\text { PD); SBP, DBP, HR ( } 40 \text { min PD); } \\
\text { MAPS, STAI-Y1 (baseline and } \\
45 \text { min PD) }\end{array}$ & $\begin{array}{l}\text { L-T slowed RT on visual probe task. } \\
\text { CA increased jitteriness and alert- } \\
\text { ness, SBP and DBP }\end{array}$ & \\
\hline \multicolumn{8}{|l|}{ EGCG } \\
\hline $\begin{array}{l}\text { Scholey et al. } \\
(2012)^{(148)}\end{array}$ & $\begin{array}{l}n 31 ; \text { mean age } \\
27 \cdot 7(\text { SD } 9 \cdot 28) \\
\text { years) }\end{array}$ & Cross-over & $\begin{array}{l}300 \text { mg EGCG. } \\
\text { Capsules. } \\
\text { Acute }\end{array}$ & Flour & $\begin{array}{l}\text { EEG at rest, Bond-Lader, stress } \\
\text { and fatigue stress (baseline and } \\
3 \mathrm{~h} P D \text { ); cognitive and CV func- } \\
\text { tioning }\end{array}$ & $\begin{array}{l}\text { EGCG increased 'calmness', reduced } \\
\text { 'stress' and increased overall eyes } \\
\text { open alpha, beta and theta activity. } \\
\text { LORETA analysis indicated activity } \\
\text { associated with frontal gyrus and } \\
\text { medial frontal gyrus }\end{array}$ & $\begin{array}{l}\text { Testing at } 10.00 \text { or } \\
14.00 \text { hours, con- } \\
\text { sistent within par- } \\
\text { ticipant. Cognitive } \\
\text { and CV data to be } \\
\text { published separ- } \\
\text { ately }\end{array}$ \\
\hline $\begin{array}{l}\text { Wightman et al. } \\
(2012)^{(147)}\end{array}$ & $\begin{array}{l}n 27 ; \text { age } 18-30 \\
\quad(\text { mean } 22) \\
\text { years }\end{array}$ & Cross-over & $\begin{array}{l}135 \text { mg EGCG; } \\
270 \text { mg } \\
\text { EGCG. Cap- } \\
\text { sules. Acute }\end{array}$ & Silica & $\begin{array}{l}\text { S3, S7, Oddball RT, RVIP, Stroop, } \\
\text { SRT, CRVAS, BP and HR } \\
\text { (baseline and } 45 \text { min PD); NIRS } \\
\text { throughout }\end{array}$ & $\begin{array}{l}135 \mathrm{mg} \text { EGCG reduced total and oxy- } \\
\text { genated Hb (NIRS) during tasks }\end{array}$ & $\begin{array}{l}\text { Testing at } 11.00 \text { or } \\
11.45 \text { hours, con- } \\
\text { sistent within par- } \\
\text { ticipant }\end{array}$ \\
\hline
\end{tabular}

CA, caffeine; L-T, L-theanine; VAS, visual analogue scales; PD, post-dose; BP, blood pressure; HR, heart rate; EEG, electroencephalography; SART, Sustained Attention to Response Task; CRT, choice reaction time; VST, Visual Search Task; EMRT, Ergocentric Mental Rotation Task; SBP, systolic blood pressure; DBP, diastolic blood pressure; RT, reaction time; IWR, immediate word recall; SRT, simple reaction time; DV, digit vigilance; RVIP, rapid visual information processing; SWM, spatial working memory; LR, logical reasoning; NWM, numeric working memory; DWR, delayed word recall; WRec, word recognition; PRec, picture recognition; SV, sentence verification; S3, serial 3 subtractions; S7, serial 7 subtractions; CRVAS, Caffeine Research Visual Analogue Scales; STAI-Y1, State Trait Anxiety Inventory state component; s-IgA, salivary IgA; ECG, electrocardiography; HRV, heart rate variability; MAS, Manifest Anxiety Scale; ALP, Alprazolam; BDI-II, Beck Depression Inventory-II; AA, anticipatory anxiety; STAI-Y2, State Trait Anxiety Inventory trait component; BAI, Beck Anxiety Inventory; CFF, critical flicker fusion; DASS, Depression, Anxiety and Stress Scales; MAPS, Mood Alertness and Physical Symptoms questionnaire; EGCG, epigallocatechin 3-gallate; CV, cardiovascular; LORETA, low-resolution brain electromagnetic tomography; NIRS, near-IR spectroscopy. 
time (SRT) and energetic arousal. The only other significant effect on mood or performance was a significant time $x$ treatment interaction, indicating a delayed effect of cocoa powder on hedonic tone, which was evident during the $2 \mathrm{~h}$ post-dose assessment as compared with the peak observed at $1 \mathrm{~h}$ following caffeine + theobromine only. This would suggest a modulation of the effects of the methylxanthines by other components when administered as cocoa powder, at least in terms of the time-course of effects. This may stem from behavioural effects of other components, or alteration in absorption time as a consequence of the food matrix. In a second study the effects of $60 \mathrm{~g}$ 'chocolate' with varying levels of methylxanthines (placebo $=$ zero; low $=8 \mathrm{mg}$ caffeine $+100 \mathrm{mg}$ theobromine; high $=20 \mathrm{mg}$ caffeine $+250 \mathrm{mg}$ theobromine) were explored. Only the high-methylxanthine treatment was shown to reduce SRT, whereas both the high- and lowmethylxanthine treatments improved accuracy of rapid visual information processing. No effects on mood were observed. It is important to note that the 'chocolate' in this study did not contain cocoa powder and therefore does not inform of the role, if any, of flavan-3-ols in these effects.

The differential contributions of caffeine and theobromine to the effects observed following their combination were explored by Mitchell et al. ${ }^{(155)}$ who examined the effects of encapsulated theobromine (700 mg), caffeine (240 mg) and their combination on mood, performance and autonomic measures as compared with placebo at 1 , 2 and $3 \mathrm{~h}$ post-ingestion. Caffeine increased alertness at each time point, as well as increasing contentment at 2 and $3 \mathrm{~h}$ post-ingestion and increasing interest in tasks and eagerness to do tasks. Theobromine decreased calmness at $3 \mathrm{~h}$ and increased interest in tasks. These effects on mood were not evident on performance measures and the combination of the two components appeared to eradicate any individual effects. As expected, caffeine increased blood pressure whilst decreasing heart rate, whereas theobromine decreased both systolic and diastolic blood pressure, and increased heart rate.

Cocoa flavan-3-ols. The majority of studies of cocoa have involved examining the effects of cocoa, containing methylxanthines, with enriched levels of flavan-3-ols. In one of the first studies to extend the findings of improved peripheral vasodilation seen following cocoa to $\mathrm{CBF}$, Sorond et al. (156) assessed the impact of short-term flavan-3-ol-rich cocoa consumption on elderly adults' CBF as assessed by transcranial Doppler. Middle cerebral artery mean blood flow velocity was assessed at baseline and following $7 \mathrm{~d}$ consumption of a dairy product-based flavan-3-ol-rich cocoa beverage containing $450 \mathrm{mg}$ flavan3-ols (with $18.3 \mathrm{mg}$ caffeine and $336.5 \mathrm{mg}$ theobromine). No effects were observed in this study, which may relate to effects of the known vasoconstrictor caffeine. Given that dietary control was simply limited to assessment taking place $\geq 2 \mathrm{~h}$ post-meal, it is possible that dietary intake of caffeine before participation resulted in a reduction of $\mathrm{CBF}$ as previously demonstrated (for example, Cameron et $a l .{ }^{(157)}$, Lunt et al. ${ }^{(158)}$, Sigmon et $a .^{(159)}$ and Kennedy \& Haskell $\left.{ }^{(160)}\right)$. Alternatively, caffeine withdrawal may have led to increases in CBF as previously shown (for example, Addicott \& Laurienti ${ }^{(16)}$ and Field et $a l^{(161)}$ ), making it difficult to demonstrate further superimposed increases. Another explanation for the lack of effects of flavan-3-ols on $\mathrm{CBF}$ is that these are only evinced when measured acutely.

Support for the assertion that CBF effects of cocoa flavan-3-ols may only be detectable acutely comes from Francis et al. ${ }^{(162)}$ who conducted a randomised, double-blind, balanced cross-over controlled trial where participants were assessed using functional MRI during a letter pair-switching task following $5 \mathrm{~d}$ consumption of flavan-3-ol-rich cocoa $(172 \mathrm{mg})$ or a matched control (13 mg flavan-3-ol). Blood oxygenation level-dependent (BOLD) signal intensity was shown to be significantly increased by flavan-3-ol-rich cocoa as compared with the control. However, despite increased activation in brain areas relevant to the task, no significant effects on cognitive performance were observed. CBF responses to either a flavan-3-ol-rich cocoa drink $(516 \mathrm{mg}$ ) or control $(39 \mathrm{mg})$ at 2,4 and $6 \mathrm{~h}$ post-consumption using arterial spin labelling also showed significant increases in grey matter $\mathrm{CBF}$ at $2 \mathrm{~h}$ following flavan-3-ol-rich cocoa, with a return to baseline levels achieved by $6 \mathrm{~h}$ post-consumption ${ }^{(162)}$. In the only study to date to detect an effect of cocoa flavan-3-ols on cognition (as compared with a methylxanthine-matched placebo), Scholey et al. ${ }^{\text {(163) }}$ reported significant improvements $90 \mathrm{~min}$ post-administration of flavan-3-ol-enriched cocoa at levels of 520 and $994 \mathrm{mg}$. Of the two enriched drinks, the $520 \mathrm{mg}$ drink was more effective, leading to consistent improvements to serial threes performance and a robust attenuation of mental fatigue increases induced by performance of the demanding tasks. More recently, Camfield et al. ${ }^{(164)}$ explored the effects of chronic cocoa flavan-3-ol consumption in the absence of an acute dose following low $(0 \mathrm{mg})$, medium (250 mg) and high (500 mg) levels in a sample of 40- to 65-year-olds. Steady-state visually evoked potentials (SSVEP) were recorded using steady-state probe topography, a form of electrophysiological brain imaging that measures steady-state evoked potentials in response to task-irrelevant visual flickers, similar to event-related potentials but with greater temporal resolution. Assessments at baseline and following $30 \mathrm{~d}$ supplementation, whilst participants completed a spatial working memory task, showed a decrease in posterior-parietal SSVEP amplitude following the medium flavan-3-ol dose as compared with placebo. In light of a lack of effects on cognition, it is suggested by the authors that this decrease in amplitude may reflect an increase in neural efficiency, whereby participants are able to perform at the same level with reduced activation. 
Despite mixed findings with regards cognition, the effects of cocoa on CBF are extremely promising and data from Field et al. ${ }^{(152)}$ and Scholey et al. ${ }^{(163)}$ show that cognitive benefits are possible, with the latter demonstrating these effects independently of methylxanthine content. Irrespective of behavioural benefits, the vascular effects of cocoa are certainly of interest. The potential of cocoa present in chocolate, a food that is viewed as palatable by the majority of the population, to provide benefits in preventing conditions such as stroke and vascular dementia is an exciting proposition worthy of further exploration.

Randomised controlled trials of cocoa are summarised in Table 3.

\section{Guaraná (Paullinia cupana)}

The plant species guaraná originates from the central Amazonian Basin, and has a long history of local usage, initially as a stimulant by indigenous people ${ }^{(165)}$, and more recently as a ubiquitous ingredient in Brazilian soft drinks. The putative stimulant properties are generally taken to reflect the presence of caffeine, which comprises $2.5-5 \%$ of the extract's dry weight, although other purine alkaloids (theophylline and theobromine) are present in smaller quantities ${ }^{(166)}$. Guaraná also has a high content of saponins, tannins ${ }^{(167)}$ and catechins (see Carlson \& Thompson ${ }^{(168)}$ ), and these may well underlie the demonstrated antioxidant properties of the plant ${ }^{(169)}$.

Few studies to date have examined the cognitive effects of guaraná in human subjects (and some of these include guaraná co-administered with other potentially psychoactive components - see Table 4 for a summary). The first controlled study in healthy young adults administered guaraná for $3 \mathrm{~d}$ at a dose of $1000 \mathrm{mg}$ then assessed effects acutely at $1 \mathrm{~h}$ post-dose. No effects were found on tests of psychomotor speed and accuracy, working memory, episodic memory, or the mosaic test ${ }^{(170)}$. In addition, no effects on anxiety or quality of sleep were observed. In a follow-up study the same doses and tasks were used to assess chronic ( 5 months) effects in an elderly population. Only one improvement was observed, a significant effect of guaraná on mosaic performance at 5 months ${ }^{(171)}$.

More recently a randomised, double-blind, placebocontrolled, counterbalanced study examined the effects of a range of doses $(37 \cdot 5,75,150$ and $300 \mathrm{mg})$ of guaraná (standardised to $11 \%$ caffeine), over the course of $6 h^{(172)}$. Improvements to a 'secondary memory' factor following both 37.5 and $75 \mathrm{mg}$ guaraná were observed, as well as increased self-rated 'alertness' following the highest dose and increases in self-rated 'contentment' following all doses of guaraná. The low level of caffeine in the doses of guaraná with the memory-enhancing effects ( 4.5 and $9 \mathrm{mg}$ caffeine) and a declining pattern of effects with ascending dose in terms of 'contentment' suggest that these effects were not attributable to the caffeine content of the guaraná. These results also shared some similarities with another study examining the effects of the same $75 \mathrm{mg}$ extract of guaraná, $200 \mathrm{mg}$ of ginseng and their combination over the course of $6 \mathrm{~h}$. Improvements to a 'speed of attention' factor, a serial sevens subtraction task and a sentence verification task were observed following $75 \mathrm{mg}$ of guaraná. Although less pronounced, performance on the 'secondary memory' factor was again improved at $2.5 \mathrm{~h}$ post-dose ${ }^{(173)}$. A vitamin/mineral preparation supplemented with $222 \mathrm{mg}$ guaraná also showed positive effects on performance of a rapid visual information processing task, coupled with an attenuation of mental fatigue associated with task performance ${ }^{(174)}$.

The limited literature on behavioural effects of guaraná suggests that caffeine content alone does not account for any behavioural effects observed, with multi-dose exploration of guaraná suggesting that $75 \mathrm{mg}$ (containing only $9 \mathrm{mg}$ caffeine) was the optimum of those doses studied. Obviously, the lower doses of guaraná also contained lower doses of any other potential active ingredients, but since so little is known about the other constituents of guaraná - its effects so often being attributed to caffeine - it is difficult to assess what level of these constituents is the optimum, or indeed what level is present. It is also possible that at higher doses, the effects of the higher levels of caffeine are in some way masking the effects of the other active ingredients. This highlights the complexity of studying naturally concomitant psychoactives. As saponins and tannins have effects that may, directly or indirectly, affect behaviour, it is extremely likely that any effects of caffeine within guaraná are concomitant with effects of other components. It is also possible that guaraná simply has no behavioural effects as suggested by null findings ${ }^{(170,171)}$; however, the lack of observed effects in these studies must be considered in light of a lack of effects of $25 \mathrm{mg}$ caffeine, suggesting that the tasks employed may simply not be sensitive enough.

\section{Summary and conclusions}

A wealth of research spanning over 100 years has examined the effects of caffeine on cognition and mood in human subjects; however, research exploring the impact of other concomitant compounds is limited. This research is indicative of the prolific intake of caffeine, often being described as 'from womb to tomb'. However, aside from consumption of caffeine pills, caffeine is not consumed in isolation, and is most often consumed alongside other plant components that have demonstrated some evidence of behavioural or behaviourally relevant activity. Data from epidemiological studies also illustrate differences in the relationship with cognition or cognitive decline as a function of source of caffeine, again suggesting that cooccurring phytochemicals may underlie any effects seen. In terms of intervention studies, less research has been directed towards the effects of coffee than tea or cocoa, which is unexpected given the popularity of this drink. 


\section{畺}

Table 3. Randomised controlled trials assessing the effects of cocoa on brain function

\begin{tabular}{|c|c|c|c|c|c|c|c|}
\hline Reference & Sample & Design & Dose, vehicle, duration & Placebo & Methods & Results & Comments \\
\hline \multicolumn{8}{|l|}{ Cocoa } \\
\hline $\begin{array}{l}\text { Crews et al. } \\
(2008)^{(151)}\end{array}$ & $\begin{array}{l}n 90 ; \text { age } \geq 60 \\
\quad(\text { mean } 68 \cdot 7) \\
\text { years; Cl; } \geq 24 \\
\text { MMSE }\end{array}$ & $\begin{array}{l}\text { Parallel } \\
\text { gro- } \\
\text { ups }\end{array}$ & $\begin{array}{l}805 \mathrm{mg} \text { CF ( } 51 \mathrm{mg} \text { monomers) } \\
\text { + } 481 \mathrm{mg} \text { TB }+36 \mathrm{mg} \text { CA. } \\
\text { Chocolate }+ \text { cocoa bever- } \\
\text { age. } 6 \text { weeks }\end{array}$ & $\begin{array}{l}41 \mathrm{mg} \mathrm{CF} \\
+1 \mathrm{mg} \\
\mathrm{TB} \\
+2 \mathrm{mg} \\
\mathrm{CA}\end{array}$ & $\begin{array}{l}\text { BSRT, WMS-III Faces I and II, } \\
\text { TMT, Stroop, WAIS-III, } \\
\text { DSST, total cholesterol } \\
\text { (HDL, LDL, VLDL), TAG, C- } \\
\text { reactive protein (baseline } \\
\text { and } 6 \text { weeks). A-DACL gen- } \\
\text { eral activation, SBP, DBP, } \\
\text { HR (baseline and at } 2 \text { h PD } \\
\text { at } 3 \text { and } 6 \text { weeks) }\end{array}$ & $\begin{array}{l}\text { No positive effects. CF } \\
\text { increased HR ( } 3 \text { and } 6 \\
\text { weeks) }\end{array}$ & $\begin{array}{l}\text { Not matched for MX. About } \\
\text { three times more } \mathrm{CHO} \text { in } \\
\text { placebo due to use of } \\
\text { sugar ( } v \text {. sweetener in } \\
\text { cocoa) }\end{array}$ \\
\hline $\begin{array}{l}\text { Field et al. } \\
(2011)^{(152)}\end{array}$ & $\begin{array}{l}n 30 ; \text { age } 18-25 \\
\text { years }\end{array}$ & $\begin{array}{l}\text { Cross- } \\
\text { over }\end{array}$ & $\begin{array}{l}773 \mathrm{mg} \text { CF }+222 \mathrm{mg} \text { TB } \\
\quad+38 \mathrm{mg} \text { CA. Chocolate. } \\
\text { Acute }\end{array}$ & $\begin{array}{l}\text { White cho- } \\
\text { colate }\end{array}$ & $\begin{array}{l}\text { CS, motion coherence } \\
\text { threshold, motion integration } \\
\text { time threshold, visual spatial } \\
\text { WM, CRT ( } 2 \text { h PD) }\end{array}$ & $\begin{array}{l}\text { CF improved CS, improved } \\
\text { WM accuracy and speeded } \\
\text { motion integration and CRT }\end{array}$ & $\begin{array}{l}\text { Single blind (researcher). No } \\
\text { baseline. Placebo not MX } \\
\text { matched. CRT effect only } \\
\text { on predictable phase } \\
\text { (essentially SRT) }\end{array}$ \\
\hline \multicolumn{8}{|l|}{ Theobromine } \\
\hline $\begin{array}{l}\text { Mitchell } \\
\text { et al. } \\
(2011)^{(155)}\end{array}$ & $\begin{array}{l}\text { Females; } n 24 ; \\
\text { age } 18-70 \\
\text { (mean } 51 \cdot 1, \text { sD } \\
12 \cdot 1 \text { ) years; } \\
420 \mathrm{mg} \mathrm{CA} / \mathrm{d}\end{array}$ & $\begin{array}{l}\text { Cross- } \\
\text { over }\end{array}$ & $\begin{array}{l}700 \mathrm{mg} \text { TB; } 120 \mathrm{mg} \mathrm{CA} ; \\
700 \mathrm{mg} \text { TB }+120 \mathrm{mg} \text { CA. } \\
\text { Capsules. Acute }\end{array}$ & Cellulose & $\begin{array}{l}\text { Bond-Lader, DSST, ERTT, } \\
\text { SBP, DBP, HR (baseline; } 1 \text {, } \\
2 \text { and } 3 \text { h PD). Implicit mood } \\
\text { (1 h PD). Motivation and } \\
\text { Workload Q (3h PD) }\end{array}$ & $\begin{array}{l}\text { CA increased alertness, con- } \\
\text { tentment, interest in, and } \\
\text { eagerness to perform tasks. } \\
\text { TB reduced calmness and } \\
\text { increased interest in tasks. } \\
\text { ERRT data indicated nega- } \\
\text { tive mood was increased by } \\
\text { TB but decreased by CA. } \\
\text { CA increased SBP and DBP, } \\
\text { and decreased HR. TB } \\
\text { decreased SBP and } \\
\text { increased HR }\end{array}$ & \\
\hline $\begin{array}{l}\text { Mumford } \\
\text { et al. } \\
(1994)^{(153)}\end{array}$ & $\begin{array}{l}n 7 ; \text { age } 28-46 \\
\text { (mean } 35 \text { ) } \\
\text { years; } 330 \mathrm{mg} \\
\text { CA/d; } 25.7 \mathrm{mg} \\
\text { TB/d }\end{array}$ & $\begin{array}{l}\text { Cross- } \\
\text { over }\end{array}$ & $\begin{array}{l}560 \text { mg TB; } 178 \text { mg CA. Cap- } \\
\text { sules. } 5 \text { d }\end{array}$ & Lactose & $\begin{array}{l}\text { Subjective ratings (baseline; } \\
0 \cdot 25,0 \cdot 5,0 \cdot 75,1,1 \cdot 5,2,4 \\
8 \text { and } 12 \mathrm{~h} \mathrm{PD)}\end{array}$ & No group effects of TB & $\begin{array}{l}\text { Four out of seven lowest } \\
\text { discrimination TB at } \\
560 \mathrm{mg} \text { and } 1 \text { as low as } \\
100 \mathrm{mg}\end{array}$ \\
\hline $\begin{array}{l}\text { Smit et al. } \\
(2004)^{(154)}\end{array}$ & $\begin{array}{l}\text { 20; age } 18-56 \\
\text { (mean } 32 \cdot 6, \mathrm{sD} \\
11 \cdot 2 \text { ) years; } \\
330 \mathrm{mg} \mathrm{CA} / \mathrm{d} ; \\
100 \mathrm{mg} \mathrm{TB} / \mathrm{d}\end{array}$ & $\begin{array}{l}\text { Cross- } \\
\text { over }\end{array}$ & $\begin{array}{l}\text { CP }\left(47 \mathrm{mg} \mathrm{CF}^{\star} \text { (23 mg mono- }\right. \\
\text { mers) + } 250 \mathrm{mg} \text { TB }+19 \mathrm{mg} \\
\text { CA); } 250 \mathrm{mg} \text { TB }+19 \mathrm{mg} \text { CA. } \\
\text { Capsules. Acute }\end{array}$ & Cellulose & $\begin{array}{l}\text { Mood/state VAS, SRT, RVIP, } \\
\text { tapping (baseline; } 1 \text { and } \\
2 \mathrm{~h} \mathrm{PD)}\end{array}$ & $\begin{array}{l}\text { SRT, energetic arousal and } \\
\text { hedonic tone significantly } \\
\text { improved by CP and TB + } \\
\text { CA; TB + CA improved } \\
\text { headache }\end{array}$ & \\
\hline $\begin{array}{l}\text { Smit et al. } \\
(2004)^{(154)}\end{array}$ & $\begin{array}{l}\text { 22; age } 18-70 \\
\text { (mean } 35 \cdot 4 \\
\text { SD } 14 \cdot 2 \text { ) years; } \\
386 \mathrm{mg} \mathrm{CA} / \mathrm{d} ; \\
85 \mathrm{mg} \mathrm{TB} / \mathrm{d}\end{array}$ & $\begin{array}{l}\text { Cross- } \\
\text { over }\end{array}$ & $\begin{array}{l}100 \mathrm{mg} \text { TB }+8 \mathrm{mg} \text { CA (low } \\
\text { MX); } 250 \mathrm{mg} \text { TB }+20 \mathrm{mg} \text { CA } \\
\text { (high MX). 'Chocolate'. } \\
\text { Acute }\end{array}$ & $\begin{array}{l}\text { Zero } \mathrm{MX} \\
\quad 60 \mathrm{ml} \\
\text { water }\end{array}$ & $\begin{array}{l}\text { Mood/state VAS, SRT, RVIP, } \\
\text { tapping (baseline; } 1 \text { and } 2 \mathrm{~h} \\
\text { PD and during 'extended } \\
\text { intervention administration') }\end{array}$ & $\begin{array}{l}\text { SRT significantly reduced by } \\
\text { high MX; RVIP accuracy } \\
\text { improved by high and low } \\
\text { MX }\end{array}$ & \\
\hline \multicolumn{8}{|l|}{ Cocoa flavanols } \\
\hline $\begin{array}{l}\text { Camfield } \\
\text { et al. } \\
(2012)^{(164)}\end{array}$ & $\begin{array}{l}n 63 ; \text { age } 40-65 \\
\text { (mean } 52 \cdot 3, \text { sD } \\
7 \cdot 49 \text { ) years }\end{array}$ & $\begin{array}{l}\text { Parallel } \\
\text { gro- } \\
\text { ups }\end{array}$ & $\begin{array}{l}250 \mathrm{mg} \mathrm{CF}+240 \mathrm{mg} \text { TB } \\
\quad+18 \mathrm{mg} \text { CA; } 500 \mathrm{mg} \mathrm{CF} \\
+240 \mathrm{mg} \text { TB }+18 \mathrm{mg} \text { CA. } \\
\text { Cocoa beverage. } 30 \mathrm{~d}\end{array}$ & $\begin{array}{l}0 \text { mg CF, } \\
\text { mat- } \\
\text { ched }\end{array}$ & $\begin{array}{l}\text { SST-SSVEP, SWM (baseline } \\
\text { and PD) }\end{array}$ & $\begin{array}{l}\text { CF decreased SSVEP ampli- } \\
\text { tude }(250 \mathrm{mg}) \text { and increased } \\
\text { latency }(250 \text { and } 500 \mathrm{mg}) \text { in } \\
\text { posterior parietal regions }\end{array}$ & \\
\hline $\begin{array}{l}\text { Francis } \\
\text { et al. } \\
(2006)^{(162)}\end{array}$ & $\begin{array}{l}n 4 ; \text { age } 18-31 \\
\text { years }\end{array}$ & $\begin{array}{l}\text { Cross- } \\
\text { over }\end{array}$ & $\begin{array}{l}516 \mathrm{mg} \text { CF. Cocoa beverage. } \\
\text { Acute }\end{array}$ & $\begin{array}{l}39 \text { mg CF, } \\
\text { matched } \\
\text { for } \mathrm{MX}\end{array}$ & $\begin{array}{l}\text { CBF measured with ASL MRI } \\
\text { (baseline; 2, } 4 \text { and } 6 \mathrm{~h} \text { PD) }\end{array}$ & $\begin{array}{l}C F \text { increased CBF (peak } 2 \mathrm{~h} \text {, } \\
\text { return to baseline } 6 \mathrm{~h})\end{array}$ & \\
\hline
\end{tabular}

$560 \mathrm{mg}$ and 1 as low as

$100 \mathrm{mg}$ 


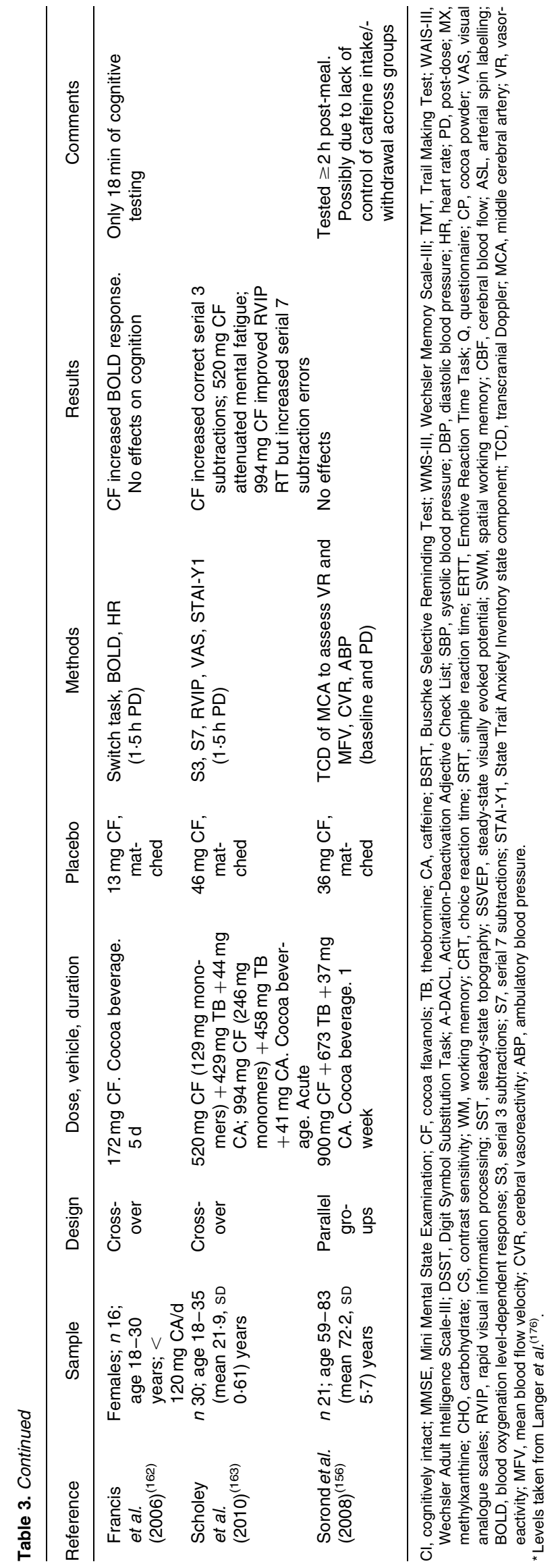

This is also surprising, as a number of epidemiological studies demonstrate habitual coffee consumption, but not tea, to have a positive association with cognitive function ${ }^{(91,96,97)}$. Although tea ${ }^{(104,105)}$ has been shown to have a negative association with cognitive impairment, only coffee, not tea, has demonstrated an inverse relationship with $\mathrm{AD}^{(96,97)}$. A number of other health benefits have been demonstrated in relation to tea ${ }^{(49-52)}$, with similar inverse relationships demonstrated for cocoa consumption $^{(55,76-78)}$, indicative of vascular improvements. These vasodilatory effects also extend to $\mathrm{CBF}$, with negative relationships with stroke being seen for both cocoa $(79,80)$ and tea ${ }^{(175)}$. Similarities in effects between tea and cocoa are unsurprising given the number of compounds shared between the two. Given these effects of tea on cerebral vasculature, and effects of EGCG in isolation on peripheral vasculature, it would seem a fair assumption that administration of EGCG would lead to increases in CBF. However, the only study to date to explore direct effects of EGCG on $\mathrm{CBF}$ demonstrated a decrease in total and oxygenated $\mathrm{Hb}$. This is potentially expected given the myriad of effects on NO, but may also indicate a complex interaction of effects within components of tea, many of which have not been investigated in relation to cognitive effects in humans. It is also possible that the effects seen acutely following EGCG are not representative of the cumulative effect following long-term consumption.

In addition to potential problems surrounding task selection and task sensitivity, there are also a number of other issues within this field of research that the limited literature on guaraná, showing the greatest psychoactive effects at lower doses (containing very little caffeine), illustrates very well. Given the lack of previous human data, it is often difficult to select an appropriate dose and/or timeframe to test in and this can lead to an assumption that a nutritional intervention is behaviourally inactive. Referring to Tables $1-4$, it is apparent that the over-riding focus of intervention studies in this field has been on acute effects of these interventions. The one exception to this, where some consideration has been given to chronic consumption, is in research on the effects of cocoa. However, even in this instance the effects of chronic consumption have often been evaluated following an acute dose that may have opposing effects to those seen chronically. Given that the majority of these compounds are consumed daily, there is a need for further exploration of their effects long term. Another factor that becomes apparent when referring to intervention studies in this field is that the majority of studies have focused on healthy young adults, who are presumably functioning near optimal performance and are unlikely to show improvements as a consequence of a nutritional intervention. In cases where older adults are considered, participants tend to be elderly, where complications caused by concomitant medication and underlying health issues are more common, and where the potential damage caused by ageing may be too great 
Table 4. Randomised controlled trials assessing the effects of guaraná on brain function

\begin{tabular}{|c|c|c|c|c|c|c|c|}
\hline Reference & Sample & Design & Dose, vehicle, duration & Placebo & Methods & Results & Comments \\
\hline $\begin{array}{l}\text { Galduróz \& } \\
\text { Carlini } \\
\left(_{(1994)^{(170)}}\right.\end{array}$ & $\begin{array}{l}n \text { 30; age } 24-35 \\
\quad \text { median } 28 \text { ) years }\end{array}$ & $\begin{array}{l}\text { Parallel } \\
\text { groups }\end{array}$ & $\begin{array}{l}1000 \text { mg GA (21 mg CA); } \\
25 \text { mg CA. Capsules. } \\
3 \text { d }\end{array}$ & Brown sugar & $\begin{array}{l}\text { Digit span, free recall, DSST, can- } \\
\text { cellation, mosaic, sleep interfer- } \\
\text { ence, STAI (baseline; } 1 \mathrm{~h} \text { PD day } \\
1 \text { and } 1 \mathrm{~h} \mathrm{PD} \text { day } 3 \text { ) }\end{array}$ & No effects of GA or CA & \\
\hline $\begin{array}{l}\text { Galduróz \& } \\
\text { Carlini } \\
\left(_{(1996)^{(171)}}\right.\end{array}$ & $\begin{array}{l}n 45 ; \text { age }>60 \\
\quad(\text { mean } 65) \text { years }\end{array}$ & $\begin{array}{l}\text { Parallel } \\
\text { groups }\end{array}$ & $\begin{array}{l}1000 \text { mg GA ( } 21 \mathrm{mg} \mathrm{CA}) \\
25 \text { mg CA. Capsules. } \\
5 \text { months }\end{array}$ & Brown sugar & $\begin{array}{l}\text { Digit span, free recall, DSST, can- } \\
\text { cellation, mosaic, Raven-pro- } \\
\text { gressive matrices, sleep } \\
\text { interference, STAI (baseline; } 3 \\
\text { and } 5 \text { months PD) }\end{array}$ & $\begin{array}{l}\text { GA improved mosaic performance } \\
\text { at } 5 \text { months }\end{array}$ & $\begin{array}{l}\text { Marked but NS } \\
\text { baseline } \\
\text { differences in } \\
\text { mosaic test }\end{array}$ \\
\hline $\begin{array}{l}\text { Haskell et al. } \\
\qquad(2007)^{(172)}\end{array}$ & $\begin{array}{l}n \text { 21; age } 18-31 \\
\text { (mean } 21 \cdot 7 \\
\text { SD } 3.52) \text { years }\end{array}$ & Cross-over & $\begin{array}{l}\text { 37.5; 75; } 150 \text { and } 300 \mathrm{mg} \\
\text { GA (all } 11-12 \% \mathrm{CA}) . \\
\text { Capsules. Acute }\end{array}$ & Lactose & $\begin{array}{l}\text { CDR: speed of attention, speed of } \\
\text { memory, accuracy of attention, } \\
\text { secondary memory, working } \\
\text { memory; RVIP; logical reasoning; } \\
\text { Bond-Lader VAS (baseline; } 1,3 \\
\text { and } 6 \text { h PD) }\end{array}$ & $\begin{array}{l}\text { Secondary memory improved by } \\
37.5 \mathrm{and} 75 \mathrm{mg} \text {. Alert improved } \\
\text { by } 300 \mathrm{mg} \text {. All doses improved } \\
\text { content. No interactions with time }\end{array}$ & \\
\hline $\begin{array}{l}\text { Kennedy et al. } \\
(2004)^{(173)}\end{array}$ & $\begin{array}{l}n \text { 28; age } 18-24 \\
\text { (mean } 31.4 \\
\text { SD } 0.77) \text { years }\end{array}$ & Cross-over & $\begin{array}{l}75 \text { mg GA }(11-12 \% \text { CA }) \\
200 \text { mg PG; } 75 \mathrm{mg} \mathrm{GA} \\
\text { +200 mg PG. } \\
\text { Capsules. Acute }\end{array}$ & $\begin{array}{l}0 \mathrm{mg} \mathrm{GA} \\
\text { or PG }\end{array}$ & $\begin{array}{l}\text { CDR: speed of attention, speed of } \\
\text { memory, accuracy of attention, } \\
\text { secondary memory, working } \\
\text { memory; logical reasoning; SV; } \\
\text { S3 and S7 subtractions; Bond- } \\
\text { Lader VAS (baseline; 1, 2.5, } 4 \\
\text { and } 6 \text { h PD) }\end{array}$ & 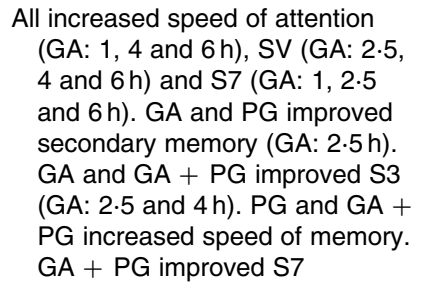 & \\
\hline $\begin{array}{l}\text { Kennedy et al. } \\
\quad(2008)^{(174)}\end{array}$ & $\begin{array}{l}n \text { 129; age } 18-24 \\
\text { (mean 21.0; } \\
\text { SD 1.60) years; } \\
\text { regular CA } \\
\text { consumers }\end{array}$ & $\begin{array}{l}\text { Parallel } \\
\text { groups }\end{array}$ & $\begin{array}{l}\text { Berocca Boost with } \\
222 \cdot 2 \mathrm{mg} \text { GA ( } 40 \mathrm{mg} \\
\text { CA). Effervescent tablet } \\
\text { in } 200 \mathrm{ml} \text { water. Acute }\end{array}$ & $\begin{array}{l}\text { Placebo } \\
\text { efferves- } \\
\text { cent tablet } \\
\text { in } 200 \mathrm{ml} \\
\text { water }\end{array}$ & $\begin{array}{l}\text { CDB: S3, S7, RVIP, mental fatigue } \\
\text { VAS } \times 6 \text {; salivary CA (baseline } \\
\text { and } 30 \text { min PD) }\end{array}$ & $\begin{array}{l}\text { Berocca Boost increased speed (no } \\
\text { time interactions) and improved } \\
\text { accuracy of RVIP (all six rep- } \\
\text { etitions); attenuated increase in } \\
\text { 'fatigue' (repetitions 3-6) and } \\
\text { increased salivary CA }\end{array}$ & \\
\hline
\end{tabular}


to be overcome by these compounds. Sample sizes in these studies also tend to be very low, which could result in null findings or, conversely, spurious significant findings. Another problem inherent here is that caffeine is likely to have a greater effect than its concomitant compounds and may therefore mask any effects exerted by them. A number of studies in this area fail to describe restrictions placed on caffeine consumption before participation and more importantly do not take into consideration the habitual caffeine consumption of participants, which given the potential impact of withdrawal and/or tolerance in relation to caffeine should be considered in all studies that involve caffeine administration. An additional concern when studying plants is the variability in levels of compounds, with the majority of extracts being standardised to caffeine content only.

Of the non-methylxanthine compounds covered in the present review, only the tea components EGCG and L-theanine have been considered in isolation. Data from these studies published to date have generally failed to show any effects on cognition, despite showing modulation of brain activity as indexed through EEG or changes in CBF. This may suggest that the physiological effects of these compounds are not evident on behaviour or that in isolation they are too subtle to be detected by the majority of cognitive tasks. Findings from Foxe et al. ${ }^{(138)}$ showing previously elusive improvements following L-theanine may provide support for the assertion that these effects are detectable with appropriate sensitive tasks. Similar findings from the cocoa flavan-3-ol literature demonstrate that this problem may not be restricted to studies that have considered the effects of compounds in isolation, with a number of studies failing to show any effects on cognition despite modulation of activity in brain areas relevant to the task employed ${ }^{(151,162,164)}$. This may indicate that the tasks employed simply are not sensitive enough to detect these changes, that the participants are performing at ceiling and that other cohorts may show an effect, or that the intervention period is not long enough for beneficial effects to be seen. Positive effects of cocoa on cognition presented $^{(152,163)}$ would seem to dispute the impact of ceiling effects or length of intervention, having shown acute effects in healthy young adults. However, given the paucity of research in this area and the exploratory nature of the trials conducted it remains possible that these compounds simply do not affect behaviour.

Further research in this area is warranted, not least because of the extremely high level of intake of caffeinated beverages, which contain a number of other components that have been shown to have activity relevant to brain function, either in vitro or in vivo. Although it is important to assess the impact of these compounds in isolation, it is also important to be aware that this may not reflect the effect elicited when consumed with caffeine or as a whole. Each of these compounds is likely to have its own peak level in terms of effects on behaviour but this is also liable to be modulated by the combination with other substances. In terms of exploring ecologically valid effects, the most informative approach to studying this would seem to be that employed in the cocoa literature, whereby cocoa enriched with flavan-3-ols is compared with a control with low levels of flava-3-ols but matched for caffeine level.

\section{Acknowledgements}

This review received no specific grant from any funding agency in the public, commercial or not-for-profit sectors. Each author contributed to the writing of the manuscript. The authors declare no conflicts of interest.

\section{References}

1. Heatherley SV, Mullings EL, Tidbury MA, et al. (2006) Caffeine consumption among a sample of UK adults. Appetite 47, 266.

2. Fredholm BB, Battig K, Holmen J, et al. (1999) Actions of caffeine in the brain with special reference to factors that contribute to its widespread use. Pharmacol Rev 51, $83-133$.

3. Hollingworth H (1912) The influence of caffeine on mental and motor efficiency. Arch Psychol 22, 1-166.

4. Magkos F \& Kavouras SA (2005) Caffeine use in sports, pharmacokinetics in man, and cellular mechanisms of action. Crit Rev Food Sci Nutr 45, 535-562.

5. Daly J (1993) Mechanism of action of caffeine. In Caffeine, Coffee, and Health, pp. 97-150 [S Garattini, editor] New York: Raven Press.

6. Umemura T, Higashi Y, Soga J, et al. (2006) Acute administration of caffeine on vascular function in humans: as a balance of endothelium-dependent vasodilator and adenosine receptor antagonist. J Hypertens 24, 172.

7. Quinlan PT, Lane J, Moore KL, et al. (2000) The acute physiological and mood effects of tea and coffee: the role of caffeine level. Pharmacol Biochem Behav 66, 19-28.

8. Smit HJ \& Rogers PJ (2000) Effects of low doses of caffeine on cognitive performance, mood and thirst in low and higher caffeine consumers. Psychopharmacology (Berl) 152, 167-173.

9. Smith A, Sturgess W, Gallagher J, et al. (1999) Effects of a low dose of caffeine given in different drinks on mood and performance. Hum Psychopharmacol 14, 473-482.

10. Durlach PJ, Edmunds R, Howard L, et al. (2002) A rapid effect of caffeinated beverages on two choice reaction time tasks. Nutr Neurosci 5, 433-442.

11. Brice C \& Smith A (2001) The effects of caffeine on simulated driving, subjective alertness and sustained attention. Hum Psychopharmacol 16, 523-531.

12. Childs E \& de Wit H (2006) Subjective, behavioral, and physiological effects of acute caffeine in light, nondependent caffeine users. Psychopharmacology (Berl) 185, 514-523.

13. James JE (1994) Does caffeine enhance or merely restore degraded psychomotor performance? Neuropsychobiology 30, 124-125.

14. Richardson NJ, Rogers PJ, Elliman NA, et al. (1995) Mood and performance effects of caffeine in relation to acute and chronic caffeine deprivation. Pharmacol Biochem Behav 52, 313-320.

15. Rogers PJ, Martin J, Smith C, et al. (2003) Absence of reinforcing, mood and psychomotor performance effects of caffeine 
in habitual non-consumers of caffeine. Psychopharmacology (Berl) 167, 54-62.

16. Addicott MA \& Laurienti PJ (2009) A comparison of the effects of caffeine following abstinence and normal caffeine use. Psychopharmacology (Berl) 207, 423-431.

17. Haskell CF, Kennedy DO, Wesnes KA, et al. (2005) Cognitive and mood improvements of caffeine in habitual consumers and habitual non-consumers of caffeine. Psychopharmacology (Berl) 179, 813-825.

18. Hewlett P \& Smith A (2006) Acute effects of caffeine in volunteers with different patterns of regular consumption. Hum Psychopharmacol 21, 167-180.

19. James JE \& Rogers PJ (2005) Effects of caffeine on performance and mood, withdrawal reversal is the most plausible explanation. Psychopharmacology (Berl) 182, $1-8$.

20. Lee BL \& Ong CN (2000) Comparative analysis of tea catechins and theaflavins by high performance liquid chromatography and capillary electrophoresis. J Chromatogr A 881, 439-447.

21. Ferruzzi MG (2010) The influence of beverage composition on delivery of phenolic compounds from coffee and tea. Physiol Behav 100, 33-41.

22. Cooper KA, Campos-Gimenez E, Alvarez DJ, et al. (2007) Rapid reversed phase ultra-performance liquid chromatography analysis of the major cocoa polyphenols and inter-relationships of their concentrations in chocolate. J Agric Food Chem 55, 2841-2847.

23. Magna A, Salamao AA, Vila M, et al. (2003) Comparative study of two spectrophotometric reagents for catechol analysis in guarana seeds powder. J Braz Chem Soc $\mathbf{1 4}$ 129-132.

24. Farah A, De Paulis T, Trugo LC, et al. (2005) Effect of roasting on the formation of chlorogenic acid lactones in coffee. J Agric Food Chem 53, 1505-1513.

25. Spencer J (2010) Beyond antioxidants: the cellular and molecular interactions of flavonoids and how these underpin their actions on the brain. Proc Nutr Soc 69, 244-260.

26. Spencer JPE, Vafeiadou K, Williams RJ, et al. (2012) Neuroinflammation: modulation by flavonoids and mechanisms of action. Mol Aspects Med 33, 83-97.

27. Williams RJ \& Spencer JPE (2012) Flavonoids, cognition, and dementia: actions, mechanisms, and potential therapeutic utility for Alzheimer disease. Free Radic Biol Med. 52, 35-45.

28. Weisburger JH (1996) Tea antioxidants and health. In Handbook of Antioxidants, pp. 469-486 [E Cadenas and L Packer, editors]. New York: Dekker.

29. Arab L, Liu W, Elashoff D, et al. (2009) Green and black tea consumption and risk of stroke: a meta-analysis. Stroke $\mathbf{4 0}$, 1786-1792.

30. Rezai-Zadeh K, Arendash GW, Hou H, et al. (2008) Green tea epigallocatechin-3-gallate (EGCG) reduces $\beta$-amyloid mediated cognitive impairment and modulates tau pathology in Alzheimer transgenic mice. Brain Res 1214, 177-187.

31. Lee YK, Yuk DY, Lee JW, et al. (2009) (-)-Epigallocatechin3-gallate prevents lipopolysaccharide-induced elevation of beta-amyloid generation and memory deficiency. Brain Res 1250, 164-174.

32. Levites Y, Amit T, Youdim MBH, et al. (2002) Involvement of protein kinase $\mathrm{C}$ activation and cell survival/cell cycle genes in green tea polyphenol (-)-epigallocatechin 3-gallate neuroprotective action. J Biol Chem 277, 30574-30580.

33. Kim SJ, Jeong HJ, Lee KM, et al. (2007) Epigallocatechin3-gallate suppresses NF- $\mathrm{KB}$ activation and phosphorylation of p38 MAPK and JNK in human astrocytoma U373MG cells. J Nutr Biochem 18, 587-596.
34. Mandel SA, Avramovich-Tirosh Y, Reznichenko L, et al. (2005) Multifunctional activities of green tea catechins in neuroprotection. Neurosignals 14, 46-60.

35. Levites Y, Weinreb O, Maor G, et al. (2001) Green tea polyphenol (-)-epigallocatechin-3-gallate prevents $N$-methyl-4phenyl-1,2,3,6-tetrahydropyridine-induced dopaminergic neurodegeneration. J Neurochem 78, 1073-1082.

36. Katiyar SK, Afaq F, Perez A, et al. (2001) Green tea polyphenol (-)-epigallocatechin-3-gallate treatment of human skin inhibits ultraviolet radiation-induced oxidative stress. Carcinogenesis 22, 287-294.

37. Chou FP, Chu YC, Hsu JD, et al. (2000) Specific induction of glutathione $S$-transferase GSTM2 subunit expression by epigallocatechin gallate in rat liver. Biochem Pharmacol 60, 643-650.

38. Xu Y, Li S, Chen R, et al. (2010) Antidepressant-like effect of low molecular proanthocyanidin in mice: involvement of monoaminergic system. Pharmacol Biochem Behav 94, 447-453

39. Choi YB, Kim YI, Lee KS, et al. (2004) Protective effect of epigallocatechin gallate on brain damage after transient middle cerebral artery occlusion in rats. Brain Res 1019, $47-54$.

40. Haque AM, Hashimoto M, Katakura M, et al. (2006) Longterm administration of green tea catechins improves spatial cognition learning ability in rats. J Nutr 136, 1043-1047.

41. Unno K, Takabayashi F, Yoshida H, et al. (2007) Daily consumption of green tea catechin delays memory regression in aged mice. Biogerontology 8, 89-95.

42. Lin YL \& Lin JK (1997) (-)-Epigallocatechin-3-gallate blocks the induction of nitric oxide synthase by down-regulating lipopolysaccharide-induced activity of transcription factor nuclear factor B. Mol Pharmacol 52, 465-472.

43. Chan MMY, Fong D, Ho CT, et al. (1997) Inhibition of inducible nitric oxide synthase gene expression and enzyme activity by epigallocatechin gallate, a natural product from green tea. Biochem Pharmacol 54, 1281-1286.

44. Stevens JF, Miranda CL, Wolthers KR, et al. (2002) Identification and in vitro biological activities of hop proanthocyanidins: inhibition of nNOS activity and scavenging of reactive nitrogen species. J Agric Food Chem 50, 3435-3443.

45. Lorenz M, Wessler S, Follmann E, et al. (2004) A constituent of green tea, epigallocatechin-3-gallate, activates endothelial nitric oxide synthase by a phosphatidylinositol-3-OH-kinase-, cAMP-dependent protein kinase-, and Akt-dependent pathway and leads to endothelial-dependent vasorelaxation. J Biol Chem 279, 6190-6195.

46. Lorenz M, Urban J, Engelhardt U, et al. (2009) Green and black tea are equally potent stimuli of NO production and vasodilation: new insights into tea ingredients involved. Basic Res Cardiol 104, 100-110.

47. Chen ZY, Law WI, Yao XQ, et al. (2000) Inhibitory effects of purified green tea epicatechins on contraction and proliferation of arterial smooth muscle cells. Acta Pharmacol Sin 21, 835-840.

48. Alvarez E, Campos M, Justiniano H, et al. (2006) Study of the mechanisms involved in the vasorelaxation induced by $(-)$

-epigallocatechin-3-gallate in rat aorta. BrJ Pharmacol 147, 269-280.

49. Widlansky ME, Hamburg NM, Anter E, et al. (2007) Acute EGCG supplementation reverses endothelial dysfunction in patients with coronary artery disease. J Am Coll Nutr 26, 95-102.

50. Shenouda SM \& Vita JA (2007) Effects of flavonoid-containing beverages and EGCG on endothelial function. $J$ Am Coll Nutr 26, 366S-372S. 
51. Alexopoulos N, Vlachopoulos C, Aznaouridis K, et al. (2008) The acute effect of green tea consumption on endothelial function in healthy individuals. Eur $J$ Cardiovasc Prev Rehabil 15, 300-305.

52. Nagaya N, Yamamoto H, Uematsu M, et al. (2004) Green tea reverses endothelial dysfunction in healthy smokers. Heart 90, 1485-1486.

53. Buijsse B, Feskens EJM, Kok FJ, et al. (2006) Cocoa intake, blood pressure, and cardiovascular mortality: the Zutphen Elderly Study. Arch Intern Med 166, 411-417.

54. Buijsse B, Weikert C, Drogan D, et al. (2010) Chocolate consumption in relation to blood pressure and risk of cardiovascular disease in German adults. Eur Heart $J$ 31, $1616-1623$.

55. Djousse L, Hopkins PN, North KE, et al. (2011) Chocolate consumption is inversely associated with prevalent coronary heart disease: The National Heart, Lung, and Blood Institute Family Heart Study. Clin Nutr 30, 182-187.

56. Fraga CG, Actis-Goretta L, Ottaviani JI, et al. (2005) Regular consumption of a flavanol-rich chocolate can improve oxidant stress in young soccer players. Clin Dev Immunol 12, $11-17$.

57. Grassi D, Lippi C, Necozione S, et al. (2005) Short-term administration of dark chocolate is followed by a significant increase in insulin sensitivity and a decrease in blood pressure in healthy persons. Am J Clin Nutr 81, 611-614.

58. Berry NM, Davison K, Coates AM, et al. (2010) Impact of cocoa flavanol consumption on blood pressure responsiveness to exercise. Br J Nutr 103, 1480-1484.

59. Faridi Z, Njike VY, Dutta S, et al. (2008) Acute dark chocolate and cocoa ingestion and endothelial function: a randomized controlled crossover trial. Am J Clin Nutr 88, 58-63.

60. Grassi D, Desideri G, Necozione S, et al. (2008) Blood pressure is reduced and insulin sensitivity increased in glucose-intolerant, hypertensive subjects after 15 days of consuming high-polyphenol dark chocolate. J Nutr $\mathbf{1 3 8}$, $1671-1676$.

61. Taubert D, Berkels R, Roesen R, et al. (2003) Chocolate and blood pressure in elderly individuals with isolated systolic hypertension. JAMA 290, 1029-1030.

62. Heiss C, Jahn S, Taylor M, et al. (2010) Improvement of endothelial function with dietary flavanols is associated with mobilization of circulating angiogenic cells in patients with coronary artery disease. J Am Coll Cardiol 56, 218-224.

63. Grassi D, Necozione S, Lippi C, et al. (2005) Cocoa reduces blood pressure and insulin resistance and improves endothelium-dependent vasodilation in hypertensives. Hypertension 46, 398-405.

64. Monagas M, Khan N, Andres-Lacueva C, et al. (2009) Effect of cocoa powder on the modulation of inflammatory biomarkers in patients at high risk of cardiovascular disease. Am J Clin Nutr 90, 1144-1150.

65. Davison K, Coates AM, Buckley JD, et al. (2008) Effect of cocoa flavanols and exercise on cardiometabolic risk factors in overweight and obese subjects. Int $J$ Obes 32, 1289-1296.

66. Heiss C, Dejam A, Kleinbongard P, et al. (2003) Vascular effects of cocoa rich in flavan-3-ols. JAMA 290, 1030-1031.

67. Mellor DD, Sathyapalan T, Kilpatrick ES, et al. (2010) High-cocoa polyphenol-rich chocolate improves HDL cholesterol in type 2 diabetes patients. Diabet Med 27, 1318-1321.

68. Njike VY, Faridi Z, Shuval K, et al. (2011) Effects of sugarsweetened and sugar-free cocoa on endothelial function in overweight adults. Int J Cardiol 149, 83-88.
69. Balzer J, Rassaf T, Heiss C, et al. (2008) Sustained benefits in vascular function through flavanol-containing cocoa in medicated diabetic patients: a double-masked, randomized, controlled trial. Circulation 51, 2141-2149.

70. Engler MB, Engler MM, Chen CY, et al. (2004) Flavonoidrich dark chocolate improves endothelial function and increases plasma epicatechin concentrations in healthy adults. J Am Coll Nutr 23, 197-204.

71. Taubert D, Roesen R, Lehmann C, et al. (2007) Effects of low habitual cocoa intake on blood pressure and bioactive nitric oxide: a randomized controlled trial. JAMA 298, 49-60.

72. Ried K, Sullivan T, Fakler P, et al. (2010) Does chocolate reduce blood pressure? A meta-analysis. BMC Med 8, 8-39.

73. Desch S, Kobler D, Schmidt J, et al. (2010) Low $v$. higherdose dark chocolate and blood pressure in cardiovascular high-risk patients. Am J Hypertens 23, 694-700.

74. Heiss C, Kleinbongard P, Dejam A, et al. (2005) Acute consumption of flavanol-rich cocoa and the reversal of endothelial dysfunction in smokers. J Am Coll Cardiol 46 , $1276-1283$.

75. Vlachopoulos C, Aznaouridis K, Alexopoulos N, et al. (2005) Effect of dark chocolate on arterial function in healthy individuals. Am J Hypertens 18, 785-791.

76. Janszky I, Mukamal KJ, Ljung R, et al. (2009) Chocolate consumption and mortality following a first acute myocardial infarction: the Stockholm Heart Epidemiology Program. J Intern Med 266, 248-257.

77. Mostofsky E, Levitan EB, Wolk A, et al. (2010) Chocolate intake and incidence of heart failure: a population-based prospective study of middle-aged and elderly women. Circ Heart Fail 3, 612-616.

78. Lewis JR, Prince RL, Zhu K, et al. (2010) Habitual chocolate intake and vascular disease: a prospective study of clinical outcomes in older women. Arch Intern Med $\mathbf{1 7 0}$, 1857-1858

79. Larsson SC, Virtamo J, Wolk A, et al. (2011) Chocolate consumption and risk of stroke in women. J Am Coll Cardiol 58, 1828-1829.

80. Buitrago-Lopez A, Sanderson J, Johnson L, et al. (2011) Chocolate consumption and cardiometabolic disorders: systematic review and meta-analysis. BMJ 343, d4488.

81. Shah ZA, Li RC, Ahmad AS, et al. (2010) The flavanol (-)-epicatechin prevents stroke damage through the Nrf2/HO1 pathway. J Cereb Blood Flow Metab 30, 1951-1961.

82. Chu YF, Brown PH, Lyle BJ, et al. (2009) Roasted coffees high in lipophilic antioxidants and chlorogenic acid lactones are more neuroprotective than green coffees. J Agric Food Chem 57, 9801-9808.

83. Kwon SH, Lee HK, Kim JA, et al. (2010) Neuroprotective effects of chlorogenic acid on scopolamine-induced amnesia via anti-acetylcholinesterase and anti-oxidative activities in mice. Eur J Pharmacol 649, 210-217.

84. Nathan PJ, Lu K, Gray M, et al. (2006) The neuropharmacology of L-theanine( $N$-ethyl-L-glutamine): a possible neuroprotective and cognitive enhancing agent. J Herb Pharmacother 6, 21-30.

85. Yokogoshi H, Kobayashi M, Mochizuki M, et al. (1998) Effect of theanine, R-glutamylethylamide, on brain monoamines and striatal dopamine release in conscious rats. Neurochem Res 23, 667-673.

86. Kimura R \& Murata T (1971) Influence of alkylamides of glutamic acid and related compounds on the central nervous system. 1. Central depressant effect of theanine. Chem Pharm Bull (Tokyo) 19, 1257-1261. 
87. Yokogoshi H, Kato Y, Sagesaka YM, Takiharamatsuura T, et al. (1995) Reduction effect of theanine on blood-pressure and brain 5-hydroxyindoles in spontaneously hypertensive rats. Biosci Biotechnol Biochem 59, 615-618.

88. Kakuda T, Nozawa A \& Sugimoto A (2002) Inhibition by theanine of binding of $\left[{ }^{3} \mathrm{H}\right] \mathrm{AMPA},\left[{ }^{3} \mathrm{H}\right] \mathrm{kainate}$, and $\left[{ }^{3} \mathrm{H}\right] \mathrm{MDL} 105,519$ to glutamate receptors. Biosci Biotechnol Biochem 66, 2683-2686.

89. Egashira N, Hayakawa K, Mishima K, et al. (2004) Neuroprotective effect of $\gamma$-glutamylethylamide (theanine) on cerebral infarction in mice. Neurosci Lett 363, 58-61.

90. Kakuda T, Yanase H, Utsunomiya K, et al. (2000) Protective effect of $\gamma$-glutamylethylamide (theanine) on ischemic delayed neuronal death in gerbils. Neurosci Lett 289, 189-192.

91. Jarvis MJ (1993) Does caffeine intake enhance absolute levels of cognitive performance. Psychopharmacology (Berl) 110, 45-52.

92. Hameleers P, Van Boxtel MPJ, Hogervorst E, et al. (2000) Habitual caffeine consumption and its relation to memory, attention, planning capacity and psychomotor performance across multiple age groups. Hum Psychopharmacol 15, 573-581.

93. van Boxtel MPJ, Schmitt JAJ, Bosma H, et al. (2003) The effects of habitual caffeine use on cognitive change: a longitudinal perspective. Pharmacol Biochem Behav $\mathbf{7 5}$, 921-927.

94. Ritchie K, Carriere I, de Mendonca A, et al. (2007) The neuroprotective effects of caffeine - a prospective population study (the Three City Study). Neurology 69, 536-545.

95. Maia L \& de Mendonca A (2002) Does caffeine intake protect from Alzheimer's disease? Eur J Neurol 9, 377-382.

96. Lindsay J, Laurin D, Verreault R, et al. (2002) Risk factors for Alzheimer's disease: a prospective analysis from the Canadian Study of Health and Aging. Am J Epidemiol 156, 445-453.

97. Eskelinen MH, Ngandu T, Tuomilehto J, et al. (2009) Midlife coffee and tea drinking and the risk of late-life dementia: a population-based CAIDE study. J Alzheimers Dis $\mathbf{1 6}$ $85-91$.

98. Johnson-Kozlow M, Kritz-Silverstein D, Barrett-Connor E, et al. (2002) Coffee consumption and cognitive function among older adults. Am J Epidemiol 156, 842-850.

99. van Gelder BM, Buijsse B, Tijhuis M, et al. (2007) Coffee consumption is inversely associated with cognitive decline in elderly European men: the FINE Study. Eur J Clin Nutr 61, 226-232

100. Wu M-S, Lan T-H, Chen C-M, et al. (2011) Socio-demographic and health-related factors associated with cognitive impairment in the elderly in Taiwan. BMC Public Health 11, 22 .

101. Laitala VS, Kaprio J, Koskenvuo M, et al. (2009) Coffee drinking in middle age is not associated with cognitive performance in old age. Am J Clin Nutr 90, 640-646.

102. Corley J, Jia X, Kyle JAM, et al. (2010) Caffeine consumption and cognitive function at age 70: The Lothian Birth Cohort 1936 Study. Psychosom Med 72, 206-214

103. Shimbo M, Nakamura K, Shi HJ, et al. (2005) Green tea consumption in everyday life and mental health. Public Health Nutr 8, 1300-1306.

104. Kuriyama S, Hozawa A, Ohmori K, et al. (2006) Green tea consumption and cognitive function: a cross-sectional study from the Tsurugaya Project. Am J Clin Nutr 83, 355-361.

105. Ng TP, Feng L, Niti M, et al. (2008) Tea consumption and cognitive impairment and decline in older Chinese adults. Am J Clin Nutr 88, 224-231.
106. Bryan J, Tuckey M, Einother SJL, et al. (2012) Relationships between tea and other beverage consumption to work performance and mood. Appetite 58, 339-346.

107. Commenges D, Scotet V, Renaud S, et al. (2000) Intake of flavonoids and risk of dementia. Eur J Epidemiol 16, 357-363.

108. Letenneur L, Proust-Lima C, Le Gouge A, et al. (2007) Flavonoid intake and cognitive decline over a 10-year period. Am J Epidemiol 165, 1364-1371.

109. Nurk E, Refsum H, Drevon CA, et al. (2009) Intake of flavonoid-rich wine, tea, and chocolate by elderly men and women is associated with better cognitive test performance. J Nutr 139, 120-127.

110. Muley A, Muley P, Shah M, et al. (2012) Coffee to reduce risk of type 2 diabetes?: a systematic review. Curr Diabetes Rev 8, 162-168.

111. Wu TY, Hankinson SE, Willett WC, et al. (2005) Caffeinated coffee, decaffeinated coffee, and caffeine in relation to plasma C-peptide levels, a marker of insulin secretion, in US women. Diabetes Care 28, 1390-1396.

112. Loopstra-Masters RC, Liese AD, Haffner SM, et al. (2011) Associations between the intake of caffeinated and decaffeinated coffee and measures of insulin sensitivity and beta cell function. Diabetologia 54, 320-328.

113. Warburton DM (1995) Effects of caffeine on cognition and mood without caffeine abstinence. Psychopharmacology (Berl) 119, 66-70.

114. Hasenfratz M \& Battig K (1994) Acute dose-effect relationships of caffeine and mental performance, EEG, cardiovascular and subjective parameters. Psychopharmacology (Berl) 114, 281-287.

115. Philip P, Taillard J, Moore N, et al. (2006) The effects of coffee and napping on nighttime highway driving: a randomized trial. Ann Intern Med 144, 785-791.

116. Smith A, Brice C, Nash J, et al. (2003) Caffeine and central noradrenaline: effects on mood, cognitive performance, eye movements and cardiovascular function. J Psychopharmacol 17, 283-292.

117. Hindmarch I, Rigney U, Stanley N, et al. (2000) A naturalistic investigation of the effects of day-long consumption of tea, coffee and water on alertness, sleep onset and sleep quality. Psychopharmacology (Berl) 149, 203-216.

118. Andrews SE, Blumenthal TD, Flaten MA, et al. (1998) Effects of caffeine and caffeine-associated stimuli on the human startle eyeblink reflex. Pharmacol Biochem Behav 59, 39-44.

119. Cropley V, Croft R, Silber B, et al. (2011) Does coffee enriched with chlorogenic acids improve mood and cognition after acute administration in healthy elderly? A pilot study. Psychopharmacology (Berl) 219, 737-749.

120. Kim J, Lee S, Shim J, et al. (2012) Caffeinated coffee, decaffeinated coffee, and the phenolic phytochemical chlorogenic acid up-regulate NQO1 expression and prevent $\mathrm{H}_{2} \mathrm{O}_{2}$ induced apoptosis in primary cortical neurons. Neurochem Int 60, 466-474.

121. Kim SS, Park RY, Jeon HJ, et al. (2005) Neuroprotective effects of 3,5-dicaffeoylquinic acid on hydrogen peroxide-induced cell death in SH-SY5Y cells. Phytother Res 19, 243-245.

122. Nakajima Y, Shimazawa M, Mishima S, et al. (2007) Water extract of propolis and its main constituents, caffeoylquinic acid derivatives, exert neuroprotective effects via antioxidant actions. Life Sci $\mathbf{8 0}, 370-377$.

123. Hwang YP \& Jeong HG (2008) The coffee diterpene kahweol induces heme oxygenase- 1 via the PI3K and p38/ Nrf2 pathway to protect human dopaminergic neurons from 6-hydroxydopamine-derived oxidative stress. FEBS Lett 582, 2655-2662. 
124. Lee KJ \& Jeong HG (2007) Protective effects of kahweol and cafestol against hydrogen peroxide-induced oxidative stress and DNA damage. Toxicol Lett 173, 80-87.

125. Kim JY, Jung KS, Jeong HG, et al. (2004) Suppressive effects of the kahweol and cafestol on cyclooxygenase-2 expression in macrophages. FEBS Lett 569, 321-326.

126. Kim JY, Jung KS, Lee KJ, et al. (2004) The coffee diterpene kahweol suppress the inducible nitric oxide synthase expression in macrophages. Cancer Lett 213, 147-154.

127. Quinlan P, Lane J, Aspinall L, et al. (1997) Effects of hot tea, coffee and water ingestion on physiological responses and mood: the role of caffeine, water and beverage type. Psychopharmacology (Berl) 134, 164-173.

128. Hindmarch I, Quinlan PT, Moore KL, et al. (1998) The effects of black tea and other beverages on aspects of cognition and psychomotor performance. Psychopharmacology (Berl) 139, 230-238.

129. Scott D, Rycroft JA, Aspen J, et al. (2004) The effect of drinking tea at high altitude on hydration status and mood. Eur J Appl Physiol 91, 493-498.

130. De Bruin EA, Rowson MJ, Van Buren L, et al. (2011) Black tea improves attention and self-reported alertness. Appetite 56, 235-240.

131. Steptoe A, Gibson EL, Vounonvirta R, et al. (2007) The effects of tea on psychophysiological stress responsivity and post-stress recovery: a randomised double-blind trial. Psychopharmacology (Berl) 190, 81-89.

132. Henry JP \& Stephens-Larson P (1984) Reduction of chronic psychosocial hypertension in mice by decaffeinated tea. Hypertension 6, 437-444.

133. Heese T, Jenkinson J, Love C, et al. (2009) Anxiolytic effects of L-theanine - a component of green tea - when combined with midazolam, in the male Sprague-Dawley rat. AANAJ 77, 445-449.

134. Kobayashi K, Nagato Y, Aoi N, et al. (1998) Effects of L-theanine on the release of alpha-brain waves in human volunteers. Nippon Nogeikagaku Kaishi 72, 153-157.

135. Nobre AC, Rao A, Owen GN, et al. (2008) L-Theanine, a natural constituent in tea, and its effect on mental state. Asia Pac J Clin Nutr 17, Suppl. 1, 167-168.

136. Gomez-Ramirez M, Higgins BA, Rycroft JA, et al. (2007) The deployment of intersensory selective attention: a high-density electrical mapping study of the effects of theanine. Clin Neuropharmacol 30, 25-38.

137. Gomez-Ramirez M, Kelly SP, Montesi JL, et al. (2009) The effects of L-theanine on alpha-band oscillatory brain activity during a visuo-spatial attention task. Brain Topogr 22, 44-51.

138. Foxe JJ, Morie KP, Laud PJ, et al. (2012) Assessing the effects of caffeine and theanine on the maintenance of vigilance during a sustained attention task. Neuropsychopharmacolgy 62, 2320-2327.

139. Kimura K, Ozeki M, Juneja LR, et al. (2007) L-Theanine reduces psychological and physiological stress responses. Biol Psychol 74, 39-45.

140. Rogers PJ, Smith JE, Heatherley SV, et al. (2008) Time for tea, mood, blood pressure and cognitive performance effects of caffeine and theanine administered alone and together. Psychopharmacology (Berl) 195, 569-577.

141. Lu K, Gray MA, Oliver C, et al. (2004) The acute effects of L-theanine in comparison with alprazolam on anticipatory anxiety in humans. Hum Psychopharmacol 19, 457-465.

142. Haskell CF, Kennedy DO, Milne AL, et al. (2008) The effects of L-theanine, caffeine and their combination on cognition and mood. Biol Psychol 77, 113-122.

143. Kelly SP, Gomez-Ramirez M, Montesi JL, et al. (2008) L-Theanine and caffeine in combination affect human cognition as evidenced by oscillatory alpha-band activity and attention task performance. J Nutr 138, 1572S-1577S.

144. Owen GN, Parnell H, De Bruin EA, et al. (2008) The combined effects of L-theanine and caffeine on cognitive performance and mood. Nutr Neurosci 11, 193-198.

145. Einother SJL, Martens VEG, Rycroft JA, et al. (2010) L-Theanine and caffeine improve task switching but not intersensory attention or subjective alertness. Appetite $\mathbf{5 4}$, 406-409.

146. Giesbrecht T, Rycroft JA, Rowson MJ, et al. (2010) The combination of L-theanine and caffeine improves cognitive performance and increases subjective alertness. Nutr Neurosci 13, 283-290.

147. Wightman EL, Haskell CF, Forster JS, et al. (2012) Epigallocatechin gallate (EGCG), cerebral blood flow parameters, cognitive performance and mood in healthy humans: a double-blind, placebo-controlled, crossover investigation. Hum Psychopharmacol 27, 177-186.

148. Scholey A, Downey LA, Ciorciari J, et al. (2012) Acute neurocognitive effects of epigallocatechin gallate (EGCG) Appetite 58, 767-770.

149. Fisher NDL, Hughes $\mathrm{M}$, Gerhard-Herman $\mathrm{M}$, et al. (2003) Flavanol-rich cocoa induces nitric-oxide-dependent vasodilation in healthy humans. J Hypertens 21, 2281-2286.

150. Flammer AJ, Hermann F, Sudano I, et al. (2007) Dark chocolate improves coronary vasomotion and reduces platelet reactivity. Circulation 116, 2376-2382.

151. Crews WD Jr, Harrison DW \& Wright JW (2008) A doubleblind, placebo-controlled, randomized trial of the effects of dark chocolate and cocoa on variables associated with neuropsychological functioning and cardiovascular health: clinical findings from a sample of healthy, cognitively intact older adults. Am J Clin Nutr 87, 872-880.

152. Field DT, Williams CM, Butler LT, et al. (2011) Consumption of cocoa flavanols results in an acute improvement in visual and cognitive functions. Physiol Behav 103, 255-260.

153. Mumford G, Evans S, Kaminski B, et al. (1994) Discriminative stimulus and subjective effects of theobromine and caffeine in humans. Psychopharmacology (Berl) 115, 1-8.

154. Smit HJ, Gaffan EA \& Rogers PJ (2004) Methylxanthines are the psycho-pharmacologically active constituents of chocolate. Psychopharmacology (Berl) 176, 412-419.

155. Mitchell ES, Slettenaar M, Van der Meer N, et al. (2011) Differential contributions of theobromine and caffeine on mood, psychomotor performance and blood pressure. $\mathrm{Phy}$ siol Behav 104, 816-822.

156. Sorond FA, Lipsitz LA, Hollenberg NK, et al. (2008) Cerebral blood flow response to flavanol-rich cocoa in healthy elderly humans. Neuropsychiatr Dis Treat 4, 433-440.

157. Cameron OG, Modell JG, Hariharan M, et al. (1990) Caffeine and human cerebral blood-flow - a positron emission tomography study. Life Sci 47, 1141-1146.

158. Lunt MJ, Ragab S, Birch AA, et al. (2004) Comparison of caffeine-induced changes in cerebral blood flow and middle cerebral artery blood velocity shows that caffeine reduces middle cerebral artery diameter. Physiol Meas 25, $467-474$.

159. Sigmon SC, Herning RI, Better W, et al. (2009) Caffeine withdrawal, acute effects, tolerance, and absence of net beneficial effects of chronic administration: cerebral blood flow velocity, quantitative EEG, and subjective effects. Psychopharmacology (Berl) 204, 573-585.

160. Kennedy DO \& Haskell CF (2011) Cerebral blood flow and behavioural effects of caffeine in habitual and nonhabitual consumers of caffeine: a near infrared spectroscopy study. Biol Psychol 86, 298-306. 
161. Field AS, Laurienti PJ, Yen YF, et al. (2003) Dietary caffeine consumption and withdrawal: confounding variables in quantitative cerebral perfusion studies? Radiology 227, $129-135$.

162. Francis ST, Head K, Morris PG, et al. (2006) The effect of flavanol-rich cocoa on the fMRI response to a cognitive task in healthy young people. J Cardiovasc Pharmacol 47, S215-S220.

163. Scholey AB, French SJ, Morris PJ, et al. (2010) Consumption of cocoa flavanols results in acute improvements in mood and cognitive performance during sustained mental effort. J Psychopharmacol 24, 1505-1514

164. Camfield DA, Scholey A, Pipingas A, et al. (2012) Steady state visually evoked potential (SSVEP) topography changes associated with cocoa flavanol consumption. Physiol Behav 105, 948-957.

165. Henman AR (1982) Guaraná (Paullinia-cupana var sorbilis): ecological and social perspectives on an economic plant of the central Amazon basin. I Ethnopharmacol 6, 311-338.

166. Weckerle CS, Stutz MA \& Baumann TW (2003) Purine alkaloids in Paullinia. Phytochemistry 64, 735-742.

167. Espinola EB, Dias RF, Mattei R, et al. (1997) Pharmacological activity of Guarana (Paullinia cupana Mart) in laboratory animals. J Ethnopharmacol 55, 223-229.

168. Carlson M \& Thompson RD (1998) Liquid chromatographic determination of methylxanthines and catechins in herbal preparations containing guarana. J AOAC Int $\mathbf{8 1}$, $691-701$.
169. Mattei R, Dias RF, Espinola EB, et al. (1998) Guarana (Paullinia cupana): toxic behavioral effects in laboratory animals and antioxidant activity in vitro. J Ethnopharmacol 60, 111-116.

170. Galduróz JC \& Carlini EA (1994) Acute effects of the Paulinia cupana, 'Guaraná' on the cognition of normal volunteers. Sao Paulo Med J 112, 607-611.

171. Galduróz JC \& Carlini EA (1996) The effects of long-term administration of guarana on the cognition of normal, elderly volunteers. Sao Paulo Med J 114, 1073-1078.

172. Haskell CF, Kennedy DO, Wesnes KA, et al. (2007) A double-blind, placebo-controlled, multi-dose evaluation of the acute behavioural effects of guarana in humans. J Psychopharmacol 21, 65-70.

173. Kennedy DO, Haskell CF, Wesnes KA, et al. (2004) Improved cognitive performance in human volunteers following administration of guarana (Paullinia cupana) extract: comparison and interaction with Panax ginseng. Pharmacol Biochem Behav 79, 401-411.

174. Kennedy DO, Haskell CF, Robertson B, et al. (2008) Improved cognitive performance and mental fatigue following a multivitamin and mineral supplement with added guaraná (Paullinia cupana). Appetite 50, 506-513.

175. Shen L, Song LG, Ma H, et al. (2012) Tea consumption and risk of stroke: a dose-response meta-analysis of prospective studies. J Zhejiang Univ Sci B 13, 652-662.

176. Langer S, Marshall LJ, Day AJ, et al. (2011) Flavanols and methylxanthines in commercially available dark chocolate: a study of the correlation with nonfat cocoa solids. J Agric Food Chem 59, 8435-8441. 